\title{
Temporal and Spatial Variations in Sand Budgets with Application to Southern Monterey Bay, California
}

\author{
Edward B. Thornton \\ Dept. of Oceanography, Naval Postgraduate School, Monterey, CA 93943 \\ thornton@nps.edu \\ 1 October 2016
}

\begin{abstract}
Often in calculating a sediment budget there is an unknown contribution, which is ascribed to the residual of the balance, and the budget cannot be fulfilled. The temporal and spatial variations and sediment size within a littoral cell provide additional information to define sediment budgets. The approach here is to consider only medium to coarse sand (grain size $>0.25 \mathrm{~mm}$ ) over a long time period during significant changes of natural and anthropogenic inputs and losses that allow calculating several budgets to isolate the unknown inputs and outputs to close the system. Considering only medium to coarse sand eliminates including the cross-shore transport of fine sand by waves, which is poorly quantified. To demonstrate these concepts, shoreline recession rates measured over a 101-year time period are used to calculate sediment budgets for southern Monterey Bay, California, littoral cells. The coarse sandy shoreline is backed by extensive bluffs and dunes that reach $44 \mathrm{~m}$ in elevation. Intensive sand mining of coarse sand derived directly from the beach and surfzone started in 1927 and continues today. A contribution of about $100 \mathrm{~K} \mathrm{~m}$ /year of medium to coarse sand from the Salinas River is calculated from measured shoreline accretion for the period 1910-1945 starting when the river first flowed into the littoral cell, prior to damming of the river and significant losses owing to sand mining. Sediment budgets are calculated for 1940-1989 and 1989-2011 to spatially identify the loss of about $200 \mathrm{~K} \mathrm{~m}$ /year attributed to different mining operations that
\end{abstract}


29 captured the littoral transport. The primary contributions of medium to coarse sand to the

30 littoral system is approximately $180 \mathrm{~K} \mathrm{~m}$ /year from the eroding dunes and beaches, Only

31 a quarter of the dune sand is found to be compatible with the coarser beach sand with the

32 finer fraction carried offshore. A conclusion is that sand mining is the cause of the

33 observed high recession rates.

34 Keywords: sediment budget, shoreline sand mining, Monterey Bay

\section{1. INTRODUCTION}

36 Sediment budgets have been shown to be useful tools in understanding regional

37 sediment processes (e.g. Rosati, 2005, Patsch and Griggs, 2007; Limber et al,, 2008). The

38 approach is to quantify the inputs, losses and storage for a littoral region, or littoral cell,

39 with well-defined lateral boundaries. The most useful boundaries are located where there

40 is a well-defined input or sink, such as a river mouth or submarine canyon. Sediment

41 inputs to a cell include rivers, bluff and dune erosion, beach nourishment, littoral

42 alongshore transport entering the cell and shoreward transport by waves. Losses include

43 littoral alongshore transport leaving the cell, sand mining, submarine canyons, cross-

44 shore transport by waves and wind. The off-shore transport by waves is not well

45 quantified. For example, assessing the amount of seaward moving sand by waves requires

46 estimating an ill-defined closure depth where the bottom profile does not change with

47 time (Hallermeier, 1978). This cross-shore transport value is often treated as an unknown

48 and appear as a residual, leaving less confidence in the budget.

49 Three approaches are proposed for solving this problem. The first approach is to

50 simplify the budget by defining a littoral cutoff diameter that determines the minimum

51 grain-size diameter of the sediments to be considered (Limber et. al., 2008). Only 
52 medium to coarse sand (grain size $>0.25 \mathrm{~mm}$, herein referred to as beach sand) will be

53 considered. Second, by considering separate, but connected littoral cells, the boundary

54 condition of the adjoining cells may be solved independently (e.g. Patsch and Griggs,

55 2008). Third, if a long enough time series of the inputs and losses are available during

56 which significant natural and anthropogenic changes occur, it may be possible to isolate

57 an unknown input or output to close the system.

58 To demonstrate these concepts, beach sand budgets in southern Monterey Bay,

59 California, (hereafter referred to as SMB) are calculated for a littoral cell from Sand City

60 to the Salinas River (Figure 1). Several sediment budgets have been calculated for SMB,

61 but considerable variations exist in the estimates (Dorman, 1968; Patsch and Griggs,

62 2007; PWA et al., 2008; amongst others). The sediment budgets are complicated by both

63 spatial and temporal changes to the inputs and losses to the littoral cell over the last

64 century. A large natural change to the littoral cell occurred when the discharge location

65 for the Salinas River changed from discharging through Elkorn Slough to north of the

66 head of the Monterey Submarine Canyon, which blocks sand from reaching SMB, to its

67 present location $6 \mathrm{~km}$ south in 1910 (Chin et al, 1988). The current Salinas River location

68 added a sediment source to the SMB littoral cell. The Salinas River was subsequently

69 dammed by the small Salinas dam in 1941 and the larger San Antonio and Naciomento

70 dams in 1956 and 1965, decreasing and modifying its input (Willis and Griggs, 2003). A

71 second, more important, anthropogenic change has been the large volumes of coarse sand

72 selectively mined directly from the surf zone and beach in SMB starting in 1927, with the

73 volumes and locations mined changing with time. 
An impetus for the sediment budget studies started in the 1970's with an attempt

75 to determine whether or not sand mining was responsible for the observed high recession

76 rates in SMB, with recession rates as much as $2 \mathrm{~m} /$ year at Fort Ord (Figure 1). SMB was

77 identified as the most erosive shoreline on average along the entire California coast over

78 the period 1945 to 1998 with an average erosion rate of $0.8 \mathrm{~m} /$ year (Hapke et al., 2006).

79 The mined sand is economically valuable owing to high silica content, hardness, grain

80 roundness, amber color and wide range of usable sizes. Uses include filtration,

81 sandblasting, foundry purposes, packing for water wells, and surface finishing

82 (Combellick and Osborne, 1977).

83 The study objectives are 1) to demonstrate techniques for calculating sediment

84 budgets by only considering the coarser fraction of the sediments, considering spatially

85 connected littoral cells to solve the boundary condition of littoral transport between them,

86 and examining a long enough time period during significant changes to calculate several

87 budgets, and 2) to provide new data on dune recession and to refine the sediment budget

88 estimates in southern Monterey Bay based on an accumulation of knowledge from recent

89 studies. The timelines of significant events are summarized in Table 1. Taking advantage

90 of temporal changes, the contribution by the Salinas River is isolated and measured

91 between when it first started flowing into SMB in 1910, before significant sand mining in

92 1945. Beach sand budgets are calculated for two time periods to examine the impact of

93 sand mining. The first budget is calculated from 1940 to 1989 during the time of

94 intensive drag-line sand mining of the surf zone focused on the south end of the littoral

95 cell. The second budget is calculated from 1989 to 2011 after all the drag-line mines were

96 closed leaving only a dredge pond mining operation at the north end of the littoral cell. 


\section{GEOLOGY SETTING}

Monterey Bay is the largest open embayment along the central California coast.

99 SMB shoreline is characterized by sandy beaches backed by dunes and pervasive sea

100 cliffs composed of Quaternary dune deposits, which will be referred to in the text as

101 dunes. The arcuate shape of the bay suggests that the bay has an equilibrium form. The

102 entire shoreline morphology is characterized as a transverse- bar and rip-beach, or

103 alternatively, low-tide terrace-bar incised by rip channels (Short, 1999).

104 Prominent morphologic features in SMB are the Monterey Submarine Canyon,

105 the sediment lobe offshore of the Salinas River, and the Point Pinos headland at the south

106 end of the bay (Figure 1), all features that significantly modify the incident wave field.

107 SMB forms a closed littoral cell bounded at the north by the Monterey Submarine

108 Canyon, which extends almost to the shoreline at Moss Landing and intercepts the

109 predominant drift from the north (Wolf, 1970; Smith et al., 2007). The effectiveness of

110 the Monterey Submarine Canyon as a barrier to littoral transport is substantiated by the

111 change in heavy mineral provinces across the canyon (Sayles, 1966) and textural and

112 petrographic differences of sand samples north and south of Moss Landing (Clark and 113 Osborne, 1982).

114 The southern end of Monterey Bay is bounded by the rocky Point Pinos headland 115 around which no sand appears to enters the bay (Storlazzi and Field, 2000). Within the

116 southern bight is the impermeable concrete wall at Wharf II built in 1950 defining the 117 eastern side of Monterey harbor located on an east-west oriented shoreline (Fig. 1). The 118 wall forms an effective barrier to littoral transport from the east, and therefore forms the 
119 southern end of the littoral cell. Locations on the map and in the text are referenced by

120 distance from Wharf II.

\section{$121 \quad 2.1$ Shelf Sediments}

122 Considerable information regarding the sediment budget is provided by 123 examining the distribution of sediment size and sand characteristics. The surface

124 sediments on the shelf based on mean grain size reveal: 1) a mid-shelf mud belt (not 125 important to this study), 2) a lobe of sediments offshore the Salinas River composed of 126 sediments $<0.25 \mathrm{~mm}, 3$ ) coarse sand deposits referred to as rippled scour depressions in

127 10-60 m water depths, and 4) a near-shore sand corridor (Eittreim et al. 2002).

128 The bulge of sediments off the Salinas River extends to water depths of 10 to 90

$129 \mathrm{~m}$. The lobe has a maximum thickness of $35 \mathrm{~m}$ located $2.5 \mathrm{~km}$ seaward of the river mouth 130 and thins in all directions. The adjacent shelf areas are characterized by a thin (2 to $5 \mathrm{~m}$ 131 thick) and uniform veneer of fine sediments. Acoustic stratigraphy of the bulge is 132 characterized by at least three uniformity-bounded depositional sequences of marine 133 deposits formed during interglacial highstands and/or during early stages of falling sea 134 level (Chin et al., 1988). Therefore, the bulge is relict, and not the result of the modern 135 relocation of the Salinas River.

136 Coarse sand occurs on the inner shelf of SMB as irregularly shaped, rippled scour 137 depressions out to depths of $60 \mathrm{~m}$ (Davis et al., 2013). This geometry is explained by 138 Eittreim et al., (2002) as a layer of $1 \mathrm{~m}$ thick fine-sand/mud overlying a widespread 139 coarse-sand layer in the subsurface that is exposed in some places by high-energy wave 140 velocities that act to ripple the coarse sediment bottom. The source of the coarse sand 
141 may be a Pleistocene transgressive lag deposit underlying much of the shelf. These coarse

142 sands do not move onshore.

\section{$143 \quad 2.2$ Beach and Dune Sand}

144 Beach and dune sand grain-size statistics have been measured by a number of 145 authors, which are summarized in Figure 2. Beach mean grain-size starts out at about 0.2 $146 \mathrm{~mm}$ at Wharf II and increases northward with a significant increase at Sand City to a

147 maximum of approximately $0.8 \mathrm{~mm}$ at Marina, followed by a decrease towards the 148 Salinas River (Figure 2). Some of the alongshore variability appears related to the 149 sampling procedures and seasonal variations, as the samples were taken both in winter 150 and summer. Based on grain-size distributions, 99\% of the beach sand between Sand City 151 and the Salinas River exceeds $0.25 \mathrm{~mm}$ in diameter (Combellick and Osborne, 1977), 152 which defines the beach sand cutoff diameter for SMB. This compares with the definition 153 by Limber et. al. (2008) where $95-98 \%$ of the all littoral sediments exceeded the littoral 154 cutoff diameter of $0.125 \mathrm{~mm}$ for the study location at Ocean Beach, California.

155 Fourier grain-shape analysis was used by Porter et al. (1979) and Clark and

156 Osborne (1982) to discriminate the more angular river sands from the dune and beach 157 sands, which are more rounded owing to originating from aeolian dune sands and 158 ongoing surf zone abrasion. They concluded that the Salinas River does not contribute a 159 significant amount of sand to the southern beaches as river sand was only detectable 160 within $2.5 \mathrm{~km}$ south of the river mouth. However, the beaches to the north of the river 161 contained numerous irregular shaped grains, strongly suggesting a fluvial source. They 162 concluded that the primary source of beach sand in SMB south of the Salinas River is 163 dune sand based on textural and petrographic analysis. 
165 at about $4.3 \mathrm{~km}$ from Wharf II (Figure 2). At approximately the same location Sayles

166 (1966) found a change in heavy-mineral composition from a predominantly hornblende

167 suite to the south to a hornblende-garnet suite to the north. He concluded that the beach

168 sand between Wharf II and Sand City is derived from the granitic rock outcropping on

169 the Monterey Peninsula. Dorman (1968) found a lobe of medium size sand offshore of

170 Sand City and concluded that this is an area of convergence (Figure 3). Clark and

171 Osborne (1982) further concluded on basis of grain-shape that the medium size sand

172 offshore and on the beach in this area are similar and have the same source. However,

173 Johnson et al. (2016) found that the sediments form only a thin veneer suggesting that

174 this is more a null point than a strong convergence. Therefore, based on these 175 sedimentological features, a littoral sub-cell boundary is defined at Sand City at $4.3+/-$

$176 \quad 0.5 \mathrm{~km}$ alongshore (Figures 1,3$)$.

177 3. WAVE CLIMATE AND LITTORAL TRANSPORT

\section{$178 \quad 3.1$ Wave Climate}

179 During the winter (November to March), northern hemisphere waves are typically

180 generated by cyclones in the north Pacific with deep water significant wave heights

181 offshore of Monterey Bay up to $11 \mathrm{~m}$, and with wave directions from north-west to west-

182 south-west (Wyland and Thornton, 1991). Local wind driven seas typically develop

183 rapidly when low pressure systems track offshore in the winter months.

184 The summer months (July to August) are a time of the most persistent winds and 185 swell waves that come from the northwest owing to a persistent high pressure system 186 offshore. Low, long period swell waves arrive from the south generated by storms in the 
187 Southern Ocean during summer months, but are generally not important in SMB as they

188 are blocked by Point Pinos. In addition, strong sea breezes and associated waves are

189 typically generated during the summer months as the result of heating of the interior land

190 of the Salinas valley located inland of Monterey Bay. In summary, the larger winter

191 storm waves tend to arrive from the west or southwest with the waves predominantly

192 from the northwest the rest of the year.

193 Long-term variations in wave climate are primarily associated with El Niño years

194 when the eastern Pacific water is warmer. The warmer water results in thermal expansion

195 raising the surface elevation along the coast order $30 \mathrm{~cm}$, and at the same time, more

196 intense storms tend to occur. The combination of the super-elevation of the water surface

197 and more intense storms results in increased beach erosion. In addition, El Niño storms

198 tend to occur later in the winter when the beach has already been narrowed by winter

199 waves, making the dunes more vulnerable to erosion.

\section{$200 \quad 3.2$ Alongshore Sediment Transport}

201 Averaged breaking wave heights for the winter months November 2007 to April

2022008 (Figure 4) were calculated by refracting directional wave spectra measured every

203 six hours by the NOAA direction wave buoy 46042 offshore Monterey Bay (Orzech

204 et.al., 2010). Wave energy focuses on Fort Ord and Marina as the waves are refracted

205 over the Monterey Submarine Canyon. The shoreline in the southern bight is sheltered by

206 Point Pinos for waves from the south and west quadrants, resulting in reduced wave

207 energy at Monterey and Sand City. The waves approach at near normal incidence all

208 along the shore owing to the narrow aperture formed by the headlands to the north and

209 south, refraction across the canyon, and historical (geological time-scale) reorientation of 
210 the shoreline in response to the wave climate. The near-normal wave incidence results in

211 well-developed rip currents and associated mega-cusps with alongshore length scale

212 ranging 200 to $1000 \mathrm{~m}$ along the entire shoreline (Thornton et al., 2007).

213 Alongshore sediment transport in SMB has been calculated by a number of

214 authors (Dorman, 1968; Orzech, et al., 2010, amongst others) with a large variation in

215 estimates. The littoral transport estimates generally agree in direction, but vary

216 considerably in magnitude. A problem is that the transport magnitude is sensitive to wave

217 direction relative to the shoreline, where the shoreline varies from east-west at Wharf II

218 to north-south at the Salinas River (Figure 1). Since the waves approach the shoreline at

219 near normal incidence owing to refraction, small errors in choosing shoreline orientation

220 can result in substantial error in the transport magnitude.

221 Orzech et al. (2010) calculated daily net sediment transport rates over a three-year

222 period (2005 to 2008) using measured wave spectra refracted from the offshore NOAA

223 wave directional buoy as input and applied the U.S. Army Coastal Engineer Research

224 Center (CERC), (2002) formulation. Orientation of the shoreline was based on recent

225 surveys. Over the same time period, Orzech et al. (2010) measured the daily migration of

226 rip current channels using time-lapse video images taken at Sand City, Fort Ord and

227 Marina (Figure 1), and hypothesized that the migration was due to alongshore sediment

228 transport. They found correlation coefficients ranged 0.76 to 0.94 between cumulative net

229 transport and daily rip channel migration distance giving confidence in the calculated

230 sediment transport values. Sediment transport at Fort Ord and Marina was seasonally

231 variable with transport to the south most of the year but with a sharp reversal to the north

232 during the winter. The calculated net transport rates were 100,000 and $50,000 \mathrm{~m}^{3} /$ year to 
233 the south at Marina and Fort Ord respectively. At Sand City, the wave directionality

234 relative to the shoreline has a more north-easterly orientation that drives a potential

235 transport consistently to the north at $33,000 \mathrm{~m}^{3} /$ year (Orzech et al., 2010). Owing to the

236 continuous curvature of the shoreline, a null point where the transport is near zero occurs

237 somewhere between the northward transport at Sand City and the net southerly transport 238 at Fort Ord.

239 The littoral transport studies show that the lobe offshore the Salinas River

240 significantly modifies wave refraction and the resulting direction of sediment transport.

241 The mean transport just south of the river and at the river mouth was found to be both

242 north and south, but north of the river the transport was found to be to the north (Figure

243 1). Therefore, SMB is additionally divided with a northern sub-cell from the Salinas

244 River mouth to the head of the Monterey Submarine Canyon at Moss Landing, and a

245 central sub-cell to the south of the Salinas River.

\section{4. SAND BUDGETS}

247 In this study, three sub-cells in SMB are identified as Wharf II to Sand City (south

248 sub-cell), Sand City to the Salinas River (central sub-cell) and the Salinas River to the

249 Monterey Submarine Canyon (north sub-cell) (Figure 1). The sand budget analysis

250 focuses on the $15.1 \mathrm{~km}$ central sub-cell ranging from Sand City at $4.3 \mathrm{~km}$ alongshore to

251 the Salinas River at $19.4 \mathrm{~km}$ alongshore (Figure 1). Only beach sand is considered in the 252 budgets.

\section{$253 \quad 4.1$ INPUTS}


255 beach sand transported alongshore, and contribution by the Salinas River. These inputs

256 are described in the following.

\section{4.1.1 Contribution from Dune Erosion}

258 A primary contribution to the sediment budget is from sand slumping onto the

259 beach during dune erosion caused by the swash of storm waves coincident with high tide

260 (maximum high tide $\sim+1 \mathrm{~m}$ relative MSL) undercutting the dune. The dune sand is

261 comprised of fine to coarse size fractions. The fine sands are sorted and carried offshore

262 by waves. The medium to coarse sand stays on the beach and is then transported

263 alongshore. Two different recession data sets are used in the sediment budgets. The first

264 data set is for the period 1940 to 2011 during the time of intensive sand mining. For this

265 data set, dune erosion is defined using the recession of the dune-top edge, which was

266 measured by Thornton et al. (2006) using a combination of stereo-photogrammetry,

267 LIDAR and GPS walking surveys over the period 1940-2005. These measurements are

268 extended here to include an additional GPS walking survey in 2011, and are referred to in

269 the figures as NPS for Naval Postgraduate School. The recession is averaged in the

270 alongshore over at least $500 \mathrm{~m}$ as there is considerable variation alongshore owing to the

271 mega-cuspate shoreline. The horizontal accuracies are estimated to be at least $\pm 2 \mathrm{~m}$ for

272 stereo-photogrammetry, $\pm 1.4 \mathrm{~m}$ for the LIDAR and $\pm 0.3 \mathrm{~m}$ for the walking GPS

273 surveys. The details of these measurement techniques are discussed in Thornton et al., 274 (2006).

275 The dune height above the dune toe elevation and beach height (dune toe 276 elevation relative to MSL) are based on a 1998 LIDAR survey augmented by a walking 
277 GPS survey in 2004. Dune height is highly variable with a maximum of $39 \mathrm{~m}$ at Fort Ord 278 (Figure 5a).

279 The average recession rate is calculated as the slope of the linear regression line 280 of the recession values as a function of time. Recession rates are calculated for two time 281 periods, first, during sand mining including drag-line operations from 1940 to 1989, and

282 second, after the drag-line mines were closed with only the dredge mine operating in

283 Marina from 1989 to 2011 (Figure 6). All linear regression fits had $\mathrm{R}^{2}$ values exceeding 2840.85 except for the recession at $13.5 \mathrm{~km}$ alongshore between 1940 and 1989, which had a 285 value of 0.22 . The error in the recession rate is the uncertainty in the regression slope 286 estimated as the difference of the minimum and maximum measurement uncertainties 287 giving a maximum error of $\pm 0.2 \mathrm{~m}$ and a time uncertainty of \pm 0.5 years. The recession 288 rates alongshore are shown in Figure $5 \mathrm{~b}$ for the two time periods.

289 4.1.2 Contribution from Beach Sand

290 Sand grains are sorted in the cross-shore and alongshore with each grain-size 291 fraction seeking an equilibrium location where gravity force and stirring by turbulent 292 wave energy balance. In the cross-shore, grain-size is a maximum near the breaker line 293 location where the turbulence levels are the highest (Dean and Dalrymple, 2002) and on 294 top of the berm carried there by the maximum wave uprush (e.g., Wiegel, 1964). The 295 finer sand tends to go offshore where wave energy is less. Medium and coarse sands tend 296 to be moved onshore by the action of swell waves owing to the inherent skewness of the 297 wave-induced velocities with the onshore velocity magnitude exceeding the offshore 298 velocity magnitude (e.g., Komar, 1998). In the case of SMB, the beach sediments are also 299 sorted alongshore with the coarse sand beaches in the central part of the bay where wave 
300 energy is greatest and with medium to fine sands progressing towards Wharf II (Figure $3012)$.

303 period between 1930 and 2001 by Reid (2004). He found the beach widths to be in a 304 steady state configuration from the Salinas River south to Monterey. Since the dune face 305 is at near angle of repose all along the shoreline owing to active erosion, the dune-top and 306 dune-toe maintain an approximate constant spatial relationship. Therefore, as recession 307 occurs, the dune-top and dune-toe recess back at the same rate as the beach in order to 308 maintain a constant width as observed by Reid (2004), which is a basic concept of this 309 analysis.

310 The cross-sectional area of beach sand is schematically represented by trapezoids 311 with the same recession widths as the dune recession width (Figure 7). Beach height is 312 equal to the difference between the elevation of the dune toe and the maximum depth of 313 medium sand (grain-size $>0.25 \mathrm{~mm}$ ), $\mathrm{h}_{\mathrm{ms}}$. The beach profiles of SMB typically have a 314 steep beach face order 1:10 to approximate MSL followed offshore by a flat, low-tide 315 terrace bar and then more steeply descending offshore. The width of the low-tide terrace 316 bar varies from about $130 \mathrm{~m}$ to $80 \mathrm{~m}$ at the rip channels at Sand City. The maximum 317 width of the low-tide terrace bar increases to over $200 \mathrm{~m}$ at Marina. Waves tend to break 318 at the change in slope at the seaward extent of the low-tide terrace bar, or at higher tides, 319 to break at the toe of the steep beach slope (Reniers et al., 2013). It is noted that the cross320 sectional area of the beach sand described by trapezoids is independent of beach slope 321 and only a function of the recession width (i.e., not the width of the beach) and combined 322 heights of the trapezoids. 
The cross-shore distribution of surficial sediment grain-size was examined in

324 comprehensive nearshore experiments at Sand City (MacMahan et al., 2005; Reniers

325 et.al, 2013). It was found that the offshore extent of medium sand (> $0.25 \mathrm{~mm}$ diameter)

326 was limited to inside the low-tide terraced bar, which extends to depth $h_{m s} \sim-1.8+/-0.2$

327 m relative MSL. The elevation of $h_{m s}$ would be expected to depend on wave height. A

328 simple first approximation is to assume that $\mathrm{h}_{\mathrm{ms}}$ is proportional to wave height calibrated

329 to the wave height at Sand City. Using the alongshore distribution of breaker wave height

330 in the winter months by Orzech et.al. (2010) shown in Figure $4, h_{m s}=-2.2 \mathrm{~m}$ for most of

331 the shoreline in the central sub-cell.

332 Dune erosion rate per unit alongshore is calculated as the dune recession rate

333 (Figure 5b) times the dune height (Figure 5a). The beach erosion rate per unit alongshore

334 is similarly calculated as dune recession rate times the beach height (schematically shown

335 in Figure 7). The total dune and beach erosion volume rates are calculated by spatially

336 integrating the dune and beach erosion rates per unit alongshore for the two time periods

337 within the central sub-cell between Sand City and the Salinas River (Table 2).

\section{$338 \quad$ 4.1.3 Contribution of Dune Sand to Beaches}

339 In the central sub-cell, the mean grain-size of the dune sand is $0.35 \mathrm{~mm}$ with only

$34022 \%$ being greater than $0.5 \mathrm{~mm}$, whereas the mean grain-size of the beach sand is 0.65

$341 \mathrm{~mm}$ with $60 \%$ being greater than $0.5 \mathrm{~mm}$. Not all dune sand is compatible with the sand

342 on the beach. The dune sand slumping onto the beach is sorted such that only the coarser

343 fraction of the dune sand is retained on the beach with the finer sands going offshore. The

344 amount of dune sand that remains on the beach is calculated based on sediment

345 distributions (Dean, 1974). The observed skewness of the beach sand is near zero in phi 
346 units (Combellick and Osborne,1977), indicating that the sediment distributions in phi

347 units are log-normal. Hence, the distributions are completely described by mean and

348 standard deviations in phi units, $\phi$, (see Table in Figure 8). The number of units of dune

349 sand, $K$, required to equal one unit of beach sand is calculated such that their

350 distributions have the same mean grain-size, where the fine fraction of dune sand is lost.

351 This requires that the 0 and $1^{\text {st }}$ moments of the truncated dune sand distribution

352 multiplied by $K$, be equal to the same moments of the beach sand distribution, as given by

$$
\int_{-\infty}^{\infty} \phi^{n} f_{\text {beach }}(\phi) d \phi=\frac{K}{\sigma_{b} \sqrt{2 \pi}} \int_{-\infty}^{\phi_{*}} \phi^{n} f_{\text {dune }}(\phi) d \phi \quad n=0,1
$$

354 where $f_{\text {beach }}(\phi)$ and $f_{\text {dune }}(\phi)$ are the log-normal sediment distributions of the beach and 355 dune, $\mathrm{n}$ is the order of the moments, $\sigma_{b}$ is the standard deviation of the beach sand, and

$356 \phi_{*}$ is the truncation limit. These result in two equations with two unknowns, $K$ and the

357 limit $\phi_{*}$, that are solved iteratively. For the areas and means of $f_{\text {beach }}(\phi)$ and the 358 partial $K f_{\text {dune }}(\phi)$ (shaded area in Figure 8) to be equal, 4 units of dune sand are required 359 to replace each unit of beach sand owing to the dune sand not only having a smaller mean 360 grain-size (smaller is larger in phi units), but is better sorted (smaller standard deviation).

361 The ratio $1 / \mathrm{K}$ is defined here as the compatibility factor. Therefore, for each volume of 362 dune sand eroded, approximately only $1 / 4$ volume is compatible with the beach sand with

$3633 / 4$ of the volume of fine sand transported offshore, which is included in the sand budgets 364 (Table 2).

\section{4.1.4 River input}

366 The original source of sand building the beaches and extensive dunes backing 367 SMB was discharge by the Salinas River at a lower stand in sea level when the river 
368 gradient was much steeper and the sediment carrying capacity of the river much greater

369 (Chin et al., 1988). As was pointed out, the discharge location of the river has changed

370 over time with the most recent change resulting in the river discharging at its present

371 location south of the Monterey Submarine Canyon starting in 1910. The Salinas River is

372 ephemeral flowing seasonally during the winter wet season. About ninety-percent of the

373 sediment is discharged between December and March during the months of peak

374 precipitation. The suspended sediment discharge is calculated using rating curves based

375 on measured suspended load as a function of measured stream flow from 1970 to 1979 at

376 a gaging station $27 \mathrm{~km}$ from the mouth of the Salinas River. The rating curves are then

377 applied to the entire time series of measured stream flow (Willis and Griggs, 2003; Gray

378 et.al., 2014; amongst others). Each study found the total average suspended sediment flux

379 to be on the order of $10^{6} \mathrm{~m}^{3} /$ year, which includes all sediment size fractions.

380 Willis and Griggs (2003) calculated annual discharge of the sand size fraction

381 (grain size $>0.063 \mathrm{~mm}$ ) from 1929 to 1999 . Suspended sand was estimated to be $15 \%$ of

382 the total suspended sediment flux. They estimated the overall uncertainty for annual

383 suspended sediment discharge to be a maximum of $\pm 37 \%$. Bedload was assumed to be

38410 percent of the total suspended sediment flux, and that all the bedload is sand size or

385 coarser. To complete the time series for this study, additional annual sand (grain size >

$3860.063 \mathrm{~mm}$ ) discharge from 2000 to 2011 are provided in Gray et.al. (2014). The interest

387 here is the contribution of medium to coarse sand. Including only grain sizes $>0.25 \mathrm{~mm}$

388 based on the sediment size distributions of river discharge given in Brownlie and Taylor

389 (1981), the suspended sediment contribution is reduced by $33 \%$ and the bedload by $42 \%$.

390 Therefore, the average annual discharge of beach-size sand from the Salinas River from 
3911929 to 1945 is estimated at $373,000 \mathrm{~m}^{3} /$ year (Table 3). Upon reaching the ocean, the

392 sand is transported both north and south in unknown proportions.

393 The amount of sand moving south from the Salinas River into the SMB central

394 sub-cell is determined by using a second shoreline recession rate data set by Hapke et al.

395 (2006). They calculated recession rates for the time periods 1854 to 1998,1910 to 1998

396 and 1945 to 1998 (Figure 9). The Hapke et al. (2006) recession rates from 1945 to 1998

397 are compared with recession rates by Thornton et al. (2006) for the same time period

398 (Figure 9). The results are consistent, giving confidence in using estimates from both

399 methods in the calculations for recession rates, at least for application to SMB. The

400 objective is to isolate the beach accretion owing to the Salinas River beach sand

401 discharge that occurred between 1910 to 1945 when the river first started contributing to

402 the SMB littoral cell and before significant sand mining. Shoreline recession rates for

4031910 to 1945 are calculated by subtracting pro-rata recession from 1945 to 1998 from

404 pro-rata recession for 1910 to 1998 to obtain recession rates from 1910 to 1945 (Figure

405 10). See Appendix A for details of the calculation. Examination of the 1910 to 1945

406 shoreline accretion rates indicates that the contribution by the Salinas River appears to

407 stop at about $15 \mathrm{~km}$ alongshore. Therefore, an estimate of the average annual volume of

408 beach size sand contributed to the SMB littoral cell by the Salinas River is obtained by

409 multiplying the shoreline accretion by the beach height (see Figure 7) and integrating

410 alongshore from $15 \mathrm{~km}$ to the Salinas River to give $101,000 \mathrm{~m}^{3} /$ year (Table 2). This value

411 represents contribution of beach sand by the river from 1910 to 1945 . Assuming that the

412 average annual discharge of beach sand from the Salinas River was constant from 1910 to

4131945 , the proportion of the annual beach sand discharge directed south into SMB is 0.27 
414 of the average total annual Salinas River beach sand discharge of $373,000 \mathrm{~m}^{3} /$ year. This

415 proportion is then applied to the measured annual river beach sand discharge to

416 determined the Salinas River input to the central littoral sub-cell for the time periods of

417 the sediment budgets (Table 3).

\section{$418 \quad$ 4.1.5 Littoral Transport from the South Sub-cell}

419 The contribution by littoral transport into the central sub-cell from the south is

420 determined by calculating sediment budgets for the southern sub-cell (Figure 1). Two

421 budgets are calculated for the time periods 1940 to 1989 and 1989 to 2011 . The inputs are

422 by dune and beach sands and some possible run-off from urban areas that is not

423 considered. Losses are due to sand transported offshore and littoral transport out of the

424 sub-cell into the central sub-cell. The littoral cutoff diameter for the southern sub-cell is

425 based on cumulative sediment grain-size distributions in Dorman (1968), where 99\% of

426 the sand exceeded $014 \mathrm{~mm}$ in diameter. The contribution of sand is calculated as the

427 recession rate times the height of the beach and dunes (Figure 7) and integrated

428 alongshore as before. The height of the beach, hms, varies as the wave height in Figure 4

429 as before. A compatibility factor for dune sand of 0.8 is calculated alongshore based of

430 the alongshore mean grain-size regression model for the beach and dune sands (Figure 2)

431 to obtain the contribution by the dune (Table 4). Only a small portion of the dune sand

432 differs in grain-size from the beach sand, which is assumed to be lost offshore. Evidence

433 that little sand is transported offshore is confirmed by the observation that much of the

434 shelf bottom at the southern end of SMB is barren of sand (Figure 3).

435 The input of sand by the beach and dune is balanced by the loss of sand

436 transported out of the sub-cell to the north (Table 4). It is noted that the amounts of 
437 available sand for transport are much less than the calculated potential transport of 33,000

$438 \mathrm{~m}^{3} /$ year by Orzech et al. (2010). The mean grain-size of the beach sand transported to the

439 north is calculated as a weighted average of the volume of beach sand alongshore times

440 the alongshore grain-size distribution (regression line in Figure 2). The calculated

441 weighted mean grain-size is $0.37 \mathrm{~mm}$, which is the same for both budget periods. This

442 grain-size is significantly smaller than the beach mean grain-size immediately upcoast in

443 the central sub-cell (Figure 2). A compatibility factor equal to 0.29 is calculated using

444 Equation 1 based on the mean sand size $(0.37 \mathrm{~mm})$ and standard deviation $(0.5)$ of the

445 incoming sand from the southern sub-cell and the mean grain-size of the beach sand $(0.65$

$446 \mathrm{~mm}$ ) of the central sub-cell to determine how much of the incoming sand contributes to

447 the beach, with the remainder being transported offshore and lost. Transport of medium

448 size sand offshore at the boundary of the two sub-cells is in accord with the sediment data

449 presented earlier that the sand size is similar to the sand size of the southern sub-cell. The

450 alongshore transport of beach sand from the south is added to the sand budget for the

451 central sub-cell (Table 2).

\section{$452 \quad 4.2$ LOSSES}

453 Losses of beach sand sand are due to sand mining, offshore transport, and reveted

454 shoreline. The loss by onshore wind is neglected because the shoreline morphology of

455 steep bluffs and dunes, except for a short length of shoreline near the Salinas River, does

456 not allow up-dune ramps for the sand to escape the beach. The transport of fine sand off-

457 shore by waves is excluded in the analysis. It is assumed the beach sand is welded to the

458 shoreline by the skewness of the waves. Reveted (e.g. seawalls) shoreline is counted as a

459 loss as it prevents dune sand from slumping onto the beaches and contributing to the 
460 system. However, there was less than $200 \mathrm{~m}$ of reveted shoreline in the central sub-cell

461 fronting Stillwell Hall at Fort Ord between 1978 to 2004 representing a negligible loss.

462 Therefore, the only loss accounted for is due to sand mining.

$463 \quad$ 4.2.1 Sand Mining

464 Southern Monterey Bay has been the most intensively mined shoreline for sand in

465 the U.S. (Magoon et al., 1972) with six commercial sites between Marina and Sand City

466 (Figure 5b). Five drag-line mines historically took coarse sand directly from the ocean at

467 Sand City and Marina starting in 1927 (Table 1). A sixth mine started in about 1965 in

468 Marina approximately $4 \mathrm{~km}$ south of the Salinas River, where the sand is hydraulically

469 mined just landward of the berm by a dredge floating on a self-made pond that acts to

470 extract sand from the littoral zone as explained below.

471 Sand mining was not regulated until 1960, when the State Lands Commission

472 asserted jurisdiction over extractions from land below MHW, which by law belongs to

473 the State of California, and began licensing the operations through issuance of leases and

474 charging royalties. The State Lands Commission imposed minimum mining amounts

475 ranging $20,000-40,000 \mathrm{~m}^{3} / \mathrm{year}$ on each company. The amount of mined sand is 476 proprietary, ostensibly to prevent price-fixing. Hence, the precise amount of sand mined

477 was unknown to the public. The U.S. Army Corps of Engineers in 1974 also required 478 leases under the Rivers and Harbors Act of 1899, which regulates activities below MHW.

479 They, however, attached maximum mining amounts to the various leases ranging 76,000 -

$480115,000 \mathrm{~m}^{3} /$ year to protect the environment. After ten-years, the Corps of Engineers 481 concluded that the sand mining caused coastal erosion, and the permits were not renewed. 
482 All mines were shut down by 1989 except the operation at Marina on the back beach 483 above the MHW line.

Thornton et al. (2006) examined the impact of sand mining on the erosion of the

485 dunes by comparing the dune recession rates before and after drag-line sand mining 486 ceased, but did not include the mining operation on the back beach at Marina. They based

487 their estimates of the amount of sand mined on scant personal communication with a 488 mine operator for the years 1984-86 and the maximum amounts allowed by the Corps of 489 Engineers permits. They concluded that the primary cause of erosion was due to sand 490 mining, and that there was a statistically significant decrease in recession rates south of 491 Sand City after drag-line sand mining ceased in 1989.

492 Since the Thornton et al., (2006) study, the actual volumes mined using drag-lines as 493 reported to the California State Lands Commission were obtained through a Freedom of 494 Information request. The volume of sand mined by year at Marina, Sand City and Total is 495 shown in Figure 11. The amounts reported were audited by the State Lands Commission 496 based on sales receipts and are deemed accurate. Some files were missing, which resulted 497 in gaps in the records. A ten-year moving average filter was used to fill the gaps. The 498 amount of sand mined shows significant year-to-year variation. The variation is due in 499 part to mining operations being interrupted by equipment damaged during winter storms 500 that took several months to repair.

501 The biggest change in the amount of sand mined was the introduction of the 502 dredging operation on the beach at Marina starting in about 1965, referred to as the Lapis 503 mine. This mining operation efficiently takes advantage of the natural cross-shore sorting 504 of sediments where coarse sediments are selectively washed over the top of the berm 
505 during times of high waves and high tide filling the pond with coarse sand. The berm

506 elevation is approximately $4 \mathrm{~m}$. The pond is effectively refilled in this manner as

507 documented by aerial photos (Figures 12).

508 Since this mine is still in operation, the volume of sand mined is proprietary.

509 Estimates of the amount of sand mined are based on initial mining volumes reported to

510 the State Lands Commission for 1965 to 1970, and the annual amount reported by the

511 new owners, CEMEX, in 2000 of at least 300,000 tons (Coast Weekly, 2006), which

512 equates to $205,000 \mathrm{~m}^{3} /$ year using the conversions in Slagel and Griggs (2008). It is

513 assumed that this was the constant amount of mining starting with introduction of a new

514 dredge boat in 1985 until the present with linear interpolations in-between (Figure 11).

515 This mining operation captures the alongshore transport of from both the north and south

516 resulting in loss of sand from the littoral budget. The sand mining losses are obtained by

517 integrating the mining curves in Figure 11 over the sand budget time periods (Table 2).

518 The biggest uncertainty in the sand budget analysis is the amount of dredge pond mining

519 (Figure 11, dashed lines).

\section{5. DISCUSSION}

\section{$521 \quad 5.1$ Assumptions of the sand budgets}

522 The residuals of the sand budgets are the balances of the inputs and losses (Table

523 2) with the expectation that if all contributions are correctly calculated the residual would

524 be zero. The residuals are non-zero, but within the margins of uncertainty of the 525 calculations.

526 Assumptions made in the sand budget analysis include: 1) The depth of medium 527 to coarse sand is limited to $h_{m s} ; 2$ ) The dredge pond sand mined since 1985 averaged 
$528205,000 \mathrm{~m}^{3} / y e a r$ based on the reported amount in 2000 and assumed to remain constant;

529 3) River sand input to SMB is based on discharge from 1929 to 1945 that does not 530 account for climate variations between 1910 to 1929. The first two assumptions are 531 discussed in the following. Climate variation is discussed in the next section, 5.2.

532 The value of $h_{m s}$ is important in determining the amount of beach erosion and the 533 baseline contribution by the Salinas River, which is measured as the volume of the 534 accretionary beach. The sensitivity of $h_{m s}$ is examined by varying its value by $\pm 25 \%$ $535( \pm 0.5 \mathrm{~m})$, which result in a \pm 8 percent differences in beach erosion when integrated 536 alongshore and \pm 7 percent differences in the baseline contribution of the Salinas River 537 for the 1989-2011 sediment budget. Similar percent changes are calculated for the 19405381989 sediment budget (Table 2). Therefore, the calculated amounts of beach erosion and 539 river input are not sensitive to error in $\mathrm{h}_{\mathrm{ms}}$.

540 An independent estimate of the volume of the dredge pond mined annually is 541 obtained by assuming the pond is effectively filled every year and subsequently dredged 542 to an area estimated from 13 aerial photos between 1998 and 2015, which range 7,000 to $54325,000 \mathrm{~m}^{2}$ with an average of $14,500 \mathrm{~m}^{2}$. The maximum depth of the dredge pond is 544 based on the depth to which the dredge head can reach, which is estimated to be at least $54511 \mathrm{~m}$ based on measurements of the dredge, plus at least a $3 \mathrm{~m}$ difference between the 546 beach and pond elevations. Applying the average pond area (accounting for angle of 547 repose of the side walls) and assuming the pond is dredged to a maximum depth of at 548 least $14 \mathrm{~m}$ below the beach elevation, the potential amount of sand mined averages $549203,000 \mathrm{~m}^{3} /$ year. However, at the same time the pond is filling, it is being mined, so that 
550 the potential amount of sand mined might be expected to be greater. This volume is

551 similar to the $205,000 \mathrm{~m}^{3} /$ year reported by the mine owners.

552 The contribution to the sand budgets by the Salinas River has decreased

553 significantly since the 1910 to 1945 baseline period (Table 3). The decrease is partially

554 attributed to the building of dams on the Salinas River. Dams reduce sediment discharge

555 by both impounding the sand behind the dams and by reducing the sediment carrying

556 capacity by reducing flow in the river, particularly during times of floods. Willis and

557 Griggs (2003) estimated that the impact of building the three dams on the Salinas River

558 was a $32 \%$ reduction in the total annual sediment flux.

\section{5.2. Climatic Variations and El Niño's}

560 A basic assumption of the analysis is that the average annual river discharge 561 measured between 1929 to 1945 is the same as during the baseline beach accretion

562 measurement period between 1910 and 1945, which ignores climatic variations. Input of

563 sand by the Salinas River is episodic with large infrequent flood events. California

564 statewide rainfall records show a cyclic nature and tend to be associated with El Niño

565 events when greater precipitation tends to occur. Although the definition of the

566 occurrence of an El Niño varies considerably, there have been approximately 8 from

567 1910-1940, 8 from 1940-1989, and 7 from 1989 to the present. Wet periods occurred

568 during 1905-1915, 1931-1944 and 1978-2010. A significant 34-year dry period occurred

569 1944-1978 (Hoell et al., 2016). The baseline river input was for the period 1910-1945,

570 which included both wet and dry periods. Unfortunately, the discharge measurements of

571 the Salinas River that would allow definitive measures of the baseline input did not start

572 until 1929, which does not include the wet period between 1910 and 1915. This would 
573 indicate that the baseline river discharge in Table 3 may be underestimated, which would

574 result in the proportion of sand contribution to SMB being smaller. Therefore, sand input

575 by the Salinas River may be overestimated for the subsequent sediment budget periods.

576 Dune and beach erosion related to wave action is highly episodic and often

577 associated with El Niño events. The strongest El Nino associated large waves since 1900

578 occurred in 1982-83 and 1997-98 (Seymour, 1998). Thornton et al. (2006) estimated that

579 the total volume loss during the $1997-1998$ winter was $2,593,000 \mathrm{~m}^{3}$, obtained by

580 integrating the erosion alongshore, of which $1,820,000 \mathrm{~m}^{3}$ is dune loss and $773,000 \mathrm{~m}^{3}$ is

581 beach loss. The dune volume loss during this El Niño winter was almost seven times the

582 historical average annual rate. This emphasizes that erosion can be highly episodic in

583 time. Surprisingly, large erosion episodes are not reflected in the recession curves, not

584 even the extreme 1982-83 and 1997-98 El Niño events are evident (Figure 6). The

585 reasons may be that input by episodic erosion events and by floods resulting in greater

586 river input tend to occur at the same time and may counter balance each other, and that

587 loss by sand mining tends to be steady.

588 5.3. Alongshore Variation of Erosion with Time and Impact of Sand Mining

589 Examination of the shoreline recession rates (Figures 5, 6, 9 and 10) suggests

590 significant alongshore variation over time. An obvious change alongshore is the shift

591 from high to lower erosion rates in the south end of the littoral cell after the closing of the

592 mines in Sand City and from lower to high erosion rates in the north end of the littoral

593 cell with the increased mining rates in Marina (Figure 5b). The recession curves shown in

594 Figure 6 provide further evidence of the temporal and spatial changes. Qualitatively the

595 change in the recession slopes at $6 \mathrm{~km}$ and $13.5 \mathrm{~km}$ alongshore suggest that there have 
596 been changes in erosion rates between the 1940's-1989 and 1989-2011. Hypothesis tests

597 were applied to determine whether the regression slopes changed between these two time

598 periods using a two-sided student-t distribution test with a 95\% level of confidence (e.g.,

599 Bowker and Liegerman, 1961). It was previously shown that erosion had statistically

600 decreased south of $4 \mathrm{~km}$ alongshore (Thornton et.al., 2006). At the north end of the

601 littoral cell at $13.5 \mathrm{~km}$ alongshore there has been a statistically significant increase in

602 erosion between these two time periods with the caveat that the earlier regression line,

603 although representative, has a low $\mathrm{R}^{2}$ value. It could not be statistically concluded that the

604 recession rates have changed in the middle sections from $6-10 \mathrm{~km}$ alongshore during

605 these same time periods.

606 The interpretation of the spatial and temporal changes in erosion volume rates is

607 complicated by the differences in dune elevation alongshore. For example, even though

608 the average shoreline recession increased in the north end of the central sub-cell between

6091989 to 2011 , the total volume contribution by dune erosion decreased because of the

610 lower dune heights in the north end.

611 The largest temporal change was from accretion to erosion about the Salinas

612 River that is seen when comparing the 1945-1998 with 1910-1998 shoreline recession

613 rates (Figure 9). The erosion coincides with the start-up and continued sand mining near

614 the river mouth. It also closely followed the damming of the Salinas River in 1956 and

615 1965. Evidence that the erosion is more associated with the mining is that the change

616 from accretion to erosion only occurs south of the river, whereas the shoreline accretion

617 rate remains essentially unchanged to the north. Further evidence suggesting that the 
618 mines intercepted the river sand is that river sand was not found south of the mine (Clark

619 and Osborne, 1982).

\section{6. SUMMARY AND CONCLUSIONS}

621 The sediment budgets of medium and coarse sand for SMB central sub-cell are

622 the sum of the input of dune and beach sands, river discharge, plus littoral transport of

623 sand from the south (Table 2). Simplification is obtained by only considering medium to

624 coarse sand that focuses on the loss of sand to the budgets owing to mining of coarse

625 sand and eliminates the not well-estimated off-shore transport of fine sand by waves. The

626 medium and coarse sand are assumed trapped along the shoreline by the velocity

627 skewness of waves. The largest inputs to the budgets are the dune sand slumping onto the

628 beach and the alongshore transport of the beach sand. It is demonstrated that only about a

629 quarter of the dune sand is of sufficient size to be compatible with the beach sand, with

630 the remainder of the fine grain sand lost to the offshore. The input of medium and coarse

631 beach sand transported alongshore is lost when it is intercepted and mined.

632 Sand budgets for the southern sub-cell were calculated to determine the littoral

633 transport input from the south into the central sub-cell. The sediment size of the southern

634 sub-cell sand is smaller and mostly incompatible with the beach sand of the central sub-

635 cell. Hence, the littoral transport from the south provides only a small contribution.

636 Examination of the dune and shoreline recession/accretion over a long time period

637 starting in 1910 to the present time provided the ability to calculate several sand budgets

638 to separate the natural input by the Salinas River and anthropogenic losses by sand

639 mining that were unique to certain time periods. Important changes to the SMB littoral

640 cell were the Salinas River input starting in 1910 followed by significant sand mining 
641 starting in the 1940's. Examination of the 1910-1945 shoreline recession rates allow

642 calculating a baseline contribution of beach sand by the Salinas River south to the SMB

643 littoral cells of approximately $100,000 \mathrm{~m}^{3} /$ year, which was 27 percent of the total river

644 discharge. The shoreline during this period was on average accreting. The subsequent

645 calculated river input account for dams built on the Salinas River, which diminished the

646 input by about 32\% (Willis and Griggs, 2003).

647 With increasingly significant sand mining, starting in the 1940's, the shoreline

648 became recessive. Two beach sand budgets are calculated to assess sand mining. The first

649 time period is from 1940 to 1989 when five drag-line sand mines taking sand directly

650 from the ocean operated in addition to a dredge-pond mine on the beach starting in about

651 1965. The second time period is from 1989 to 2011 that corresponds to after the drag-line

652 mines were shut down with only the dredge-pond mine operating in Marina. The dredge-

653 pond operation mines approximately $205,000 \mathrm{~m}^{3} / \mathrm{year}$ today, and appears to intercept

654 most all the beach size sand transported south from the Salinas River and sand

655 transported north from the beaches of the central littoral sub-cell. The impact of sand

656 mining is evidenced not only by the high overall recession rates, but also by spatial

657 changes in the rates over time. High recession rates occurred in the southern portion of

658 SMB from 1940-1989, after which there was a decrease when the mines in the south were

659 closed. A shift to higher recession rates starting in 1989 in the north portion of SMB is

660 attributed to increased dredge pond sand mining. It is concluded that sand mining is the

661 cause of the high shoreline recession rates observed in SMB, which continues today.

662

663 


\section{Appendix A. Salinas River Beach Sand Input to the Central Sub-cell.}

665 The percent of the total discharge of Salinas River beach sand that moves south

666 into the SMB central sub-cell is determined by examining the shoreline recession rates by

667 Hapke et al. (2006) for the period of time from 1910 to 1945 when the Salinas River first

668 started to discharge into SMB and before significant sand mining. For Monterey Bay,

669 Hapke et al. (2006) used surveys of the observed high-waterline (HWL) as measured as

670 the rack line from T-sheets for 1852, 1854, 1910, 1933, and 1945 combined with

671 measured MHWL obtained from a LIDAR survey in 1998. Uncertainties in

672 measurements are due to using the qualitatively observed HWL measurement and not

673 being able to account for seasonal variations since the date of the earlier surveys are

674 unknown. Composite long-term recession rates were calculated using linear regression

675 applied to shoreline positions from 1852 to 1998 for positions between $4.2 \mathrm{~km}$ and 5.2

$676 \mathrm{~km}$ alongshore, fortuitously from 1910 to 1998 for positions between 5.2 and $12.3 \mathrm{~km}$

677 alongshore, and from 1854 to 1998 for positions between 12.3 and $25 \mathrm{~km}$ alongshore.

678 The 1852 to 1998 and 1854 to 1998 recession shoreline rates are both simply referred to

679 as 1854 to 1998 (Figure 9). Short-term recession rates were calculated based on the end

680 points of the 1945 and 1998 surveys (Figure 9). The wavy shoreline recession rates are

681 the result of well-developed mega-cusps captured in the 1998 survey with an alongshore

682 averaged rms excursion value of $0.4 \mathrm{~m}$. Error analysis found a long-term error of \pm 0.1

$683 \mathrm{~m} / \mathrm{yr}$ and a short-term error of $\pm 0.4 \mathrm{~m} / \mathrm{yr}$ (Hapke et al., 2006). The wavy shorelines are

684 not indicative of long-term shorelines. Therefore, the shorelines were spatially filtered

685 using a Fourier low-pass filter with a cut-off of $1 / 2 \mathrm{~km}^{-1}$ (Figure 10). 
687 shoreline recession rate for 1910 to 1945 is calculated by subtracting the total shoreline 688 recession for 1945 to 1998 obtained by multiplying the shoreline recession rate by 53

689 years (the years of recession) from the total shoreline recession for 1910 to 1998 obtained 690 by multiplying the shoreline recession rate by 88 years, and then dividing the difference

691 in recession by 35 years, the interval between 1910 and 1945 (Figure 10, green line 692 between thin vertical lines). Additional prorated shoreline recession rates are calculated 693 in a similar manner for the section from 4.2 to $5.2 \mathrm{~km}$ alongshore for between 1852 and 6941945 (Figure 10, black line) and for the section 12.3 to $25 \mathrm{~km}$ alongshore between 1854 695 and 1945 (Figure 10, black line). The analysis shows that there was significant accretion 696 south of the Salinas River.

697 It is observed that the prorated shoreline recession rates are almost the same for 6981854 to 1945 and 1910 to 1945 where they meet at $12.3 \mathrm{~km}$ alongshore suggesting the 699 shoreline recession rate from 1854 to 1910 prior to the Salinas River flowing into SMB 700 and any sand mining was small (near zero). Therefore, it is assumed that shoreline 701 recession rate prior to 1910 was negligible between 1854 and 1910. Approximate 702 shoreline recession (accretion) rates for 1910 to 1945 are then obtained by dividing the 703 total shoreline recession between 1854 to 1945 (1854 to 1945 shoreline recession rate 704 multiplied by 91 years) by 35 years, the interval between 1910 and 1945. Combining the 705 three alongshore sections results in shoreline recession (accretion) rates from 1910 to 7061945 for the entire SMB shoreline (Figure 10, green line).

\section{Acknowledgements}


709 Dorman, L.A. Egley, J. Conforto-Sesto, W.R. Lima-Blanco, T. McGee, E. Oradiwe, M.

710 Orzech, and A.I. Sklavidis, and previous post-docs E. Gallagher, A. Reniers and J.

711 MacMahan whose cumulative research has resulted in the many of the conclusions in this

712 paper. I thank James Jackson for providing the USGS shoreline recession rates. I thank

713 Bob Battalio, Dave Revell and David Brew for their discussions on the SMB sand

714 budgets. I thank Gisele Matilla, Doug Smith and anonymous reviewers for critically

715 reviewing the manuscript. The research has been funded in part over many years by the

716 State of California, Department of Boating and Waterways and the Office of Naval

717 Research.

718

\section{REFERENCES}

721 Bowker, A.H., Lieberman, G.J., 1959. Engineering Statistics, Prentice-Hall, N.Y., 585 pp.

Brownlie, W.R., Taylor, B.D., 1981. Sediment Management for Southern California Mountains, Coastal Plains and Shoreline; Part C, Coastal Sediment Delivery by Major Rivers in Southern California. Environmental Quality Laboratory Report No. 17-C: Pasadena, California, California Institute of Technology, 314 pp.

Chin, J.L., Clifton, H.E., Mullins, H.T., 1988. Seismic stratigraphy and late Quaternary shelf history, south-central Monterey Bay, California. Marine Geology, 81, 137-157.

Clark, R.A., Osborne, R.H. 1982. Contribution of Salinas River sand to the beaches of Monterey Bay, California, during the 1978 flood period: Fourier grain-shape analysis, Journal Sedimentary Petrology, 52 (3), 807-822.

Coast Weekly, May 15, 2006. CEMEX Sand Mine in Marina.

Combellick, R.A., Osborne, R.H., 1977. Sources and petrology of beach sand from southern Monterey Bay, California. Journal Sedimentary Petrology, 47, 891-907. 
Davis, A.C.D., Kvitec, R.K., Muellwe, C.B.A., Young, M.A., Storlazzi, C.D., Phillips,

742 E.L., 2013, Distribution and abundance of rippled scour depressions along the California

743 Coast. Continental Shelf Research, 69, 88-100.

744

745

746

747

748

749

750

751

752

753

754

755

756

757

758

759

760

761

762

763

764

765

766

767

768

769

770

771

772

773

774

775

776

777

778

779

780

781

782

783

784

785
Dean, R. G., 1974. Compatibility of barrow material for beach fills, Proceedings

Fourteenth International Coastal Engineering Conference, ASCE, p 1319-1333.

Dean, R. G., Dalrymple, R.A., 2002. Coastal Processes with Engineering Applications, Cambridge University Press, 478 pp.

Dorman, C. E., 1968. The Southern Monterey Bay littoral cell: A preliminary sediment budget study, Master's thesis, Naval Postgraduate School, Monterey CA., 233 pp.

Eittreim, S.L., Anima, R.J., Stevenson, A.J. 2002. Seafloor geology of the Monterey Bay area continental shelf, Marine Geology, 181, 3-34.

Gray, A.B., Pasternack, G.B., Watson, E.B., Warrick, J.A., and Goni, M.A., 2014. The effect of El Nino Southern Oscillation cycles on the decadal scale suspended sediment behavior of a coastal dry-summer subtropical catchment, Earth Surface Processes and Landforms (wileyonlinelibrary.com) DOI: 10.1002/esp.3627.

Hallermeier, R.J., 1981. A profile zonation for seasonal sand beaches from wave climate. Coastal Engineering, 4, 253-277.

Hapke, C., D. Reid, B. M. Richmond, P. Ruggiero and J. List, 2006. National Assessment of Shoreline Change Part 3; Historical shoreline change and associated coastal land loss along sandy shorelines of the California coast: U.S. Geological Survey Open-File Report 2006-1219.

Hoell, A., Hoerling, M., Eischeid, J., Wolter, K., Dole, R., Perlwitz, J., Xu, T., Cheng, L., 2016. Does El Nino intensity matter for California precipitation? Geophysical Research Letters, 43 (2), 819-825.

Johnson, S.Y., Dartnell, P., Hartwell, S.R., Cochrane, G.R., Golden, N.E., Watt, J.T., Davenport, C.W., Kvitek, R.G., Erdey, M.D., Krigsman, L.M., Sliter, R.W., and Maier, K.L., 2016. California State Waters Map Series - Offshore of Monterey, CA. California Seafloor Mapping Program, https://walrus.wr.usgs.gov/csmp/OffshoreMonterey/

Komar, P.D., 1998. Beach Processes and Sedimentation, $2^{\text {nd }}$ edition, Prentice Hall, 544 pp.

Limber, P.W., Patsch, K.B., Griggs, G.B., 2008. Coastal Sediment Budgets and the Littoral Cutoff Diameter: A Grain Size Threshold for Quantifying Active Sediment Inputs, Journal Coastal Research. 24 (2B), 122-133. 
MacMahan, J.H., Thornton, E.B., Stanton, T.P., and Reniers, A.J.H.M., 2005. RIPEX:

Observations of a rip current system. Marine Geology, 218, 113-134.

Magoon, O. T., Haugen, J.C, Sloan, R.L., 1972. Coastal sand mining in Northern California, U.S.A., Proceedings International Conference Coastal Engineering, ASCE, 1571-1598.

Orzech, M.D., Thornton, E.B., MacMahan, J.H., O’Reilly, W.C., Stanton, T.P., 2010. Alongshore rip channel migration and sediment transport, Marine Geology, 271, 278291.

Patsch, K., Griggs, G., 2007. Development of sand budgets for California's major littoral cells, California Coastal Sediment Management Workgroup, 115 pp.

(http://dbw.ca.gov/csmw/PDF/Sand_Budgets_Major_Littoral_Cells.pdf).

Patsch, K., Griggs, G., 2008. A sand budget for the Santa Barbara Littoral Cell, California, Marine Geology, 252, 50-61.

Porter, G.A., R. Ehrlich, R.H. Osborne and R.A. Combellick, 1979. Sources and nonsources of beach sand along southern Monterey Bay, California- Fourier shape analysis, Journal Sedimentary Petrology, 49 (3), 727-732.

[PWA] Philip Williams \& Associates, Ltd, Thornton E, Dugan J, Halcrow Group, 2008. Coastal Regional Sediment Management Plan for Southern Monterey Bay. Prepared for Association of Monterey Bay Area Governments and the Coastal Sediment Management Workgroup.

http://www.dbw.ca.gov/csmw/pdf/SMontereyBay_CRSMP_3Nov2008_ALL_rev_04041 1.pdf

Reniers, A.J.H.M., Gallagher, E.L., MacMahan, J.H., Brown, J.A., van Rooijen, A.A., van Thiel de Vries, J.S.M., van Prooijen, B.C., 2013. Observations and modeling of steep-beach grain-size variability, Journal Geophysical Research: Oceans, 118, 577-591, doi:10.1029/2012JC008073.

Ried, D.W., 2004. Long-term beach width changes in Monterey Bay, California. Master of Science, University of California, Santa Cruz, 104 pp.

Rosati, J.D., 2005. Concepts in sediment budgets. Journal Coastal Research 21, 307-322.

Sayles, F.L., 1966. A reconnaissance heavy mineral study of Monterey Bay beach sediment: Hydraulic Eng. Lab. Tech. Rept. HEL-2-16, University of California, Berkeley, 18 pp.

Seymour, R. J., 1998. Effects of El Niños on the West Coast Wave Climate: Shore \& Beach, 66 (3), 3-6. 
832 Short, A.D., 1999, Handbook of Beach and Shoreface Morphodynamics, John Wiley \&

833 Sons, Inc., 379 pp.

Slagel, M.J. and Griggs, G.B. 2008. Cumulative losses of sand to the California coast by dam impoundment. Journal Coastal Research 24(3): 571-584. 94.

Storlazzi, C.D., and Field, M.E., 2000, Sediment distribution and transport along a rocky, embayed coast: Monterey Peninsula and Carmel Bay, California, Marine. Marine Geology, 170, 289-316.

Thornton, E.B., Sallenger, A.H., Conforto Sesto, J., Egley, L.A., McGee, T., Parsons, A.R., 2006. Sand Mining Impacts on Long-Term Dune Erosion in Southern Monterey Bay. Marine Geology, 229 (1-2) 45-58.

Thornton, E.B., Sallenger, A.H., MacMahan, J.H., 2007. Rip Currents, Cuspate

Shorelines and Eroding Dunes. Marine Geology, 240 (1-4), 151-167.

U.S. Army Corps of Engineers, 2002, Shore Protection Manual, $8^{\text {th }}$ ed. Coastal Engineering Research Center, Washington.

Wiegel, R.L., 1964. Oceanographical Engineering. Prentice-Hall, London/NY. 532 pp.

Willis, C.M., Griggs, G.B., 2003. Reductions in Fluvial Sediment Discharge by Coastal Dams in California and Implications for beach Sustainability, Journal of Geology, 111 (2), 167-182.

Wolf, S.C., 1970. Coastal currents and mass transport of surface sediment over the shelf regions of Monterey Bay, California. Marine Geology, 8, 321-336.

Wyland, R. M. and Thornton, E.B., 1991, Comparison of Extremal Wave Statistics Using Three Hindcast Data Sets. Journal Waterway, Ports, Coastal and Ocean, WW1(5), 60-74. 
Table 1. Time lines

1909 Sand mining started at Lapis site in Marina

885 1940-1989 Intensive drag-line sand mining directly from ocean

8861956 Naciomento Dam built on Salinas River

8871965 San Antonio Dam built on Salinas River

$888 \sim 1965$ Hydraulic sand mining by dredge boat on pond at Lapis mined started

889 1985 Larger dredge boat started mining pond at Lapis mine

8901986 Sand mining by drag-lines stopped in Marina

8911989 Sand mining by drag-lines stopped in Sand City

Table 2. Sand Budget for SMB Central Sub-cell. Values in $\mathrm{m}^{3} /$ year $\times 1^{3}$. Uncertainties are presented with the values.

Mean Recession (m)

1940-1989

1989-2011

902

Dune Erosion

$-1.0$

$-1.3$

903

Dune Erosion x compatibility factor, 0.25

190

155

904

905

Beach Erosion

$48 \pm 5$

$39 \pm 4$

906

907

908

909

910

911

912

913

914

River Input

$105 \pm 9$

$127 \pm 11$

915

916

$56 \pm 6 \quad 34 \pm 3$

917

918

919

Littoral Transport in from south

Littoral Transport in from south $\mathrm{x} 0.29$

$$
20 \pm 4
$$

$6 \pm 2$

$$
10 \pm 2
$$$$
3 \pm 1
$$

Sand Mining

$-174+43$

$-205 \pm 50$

Residuals

$41 \pm 69$ 
920 Table 3. Average annual discharge of beach sand $(>0.25 \mathrm{~mm})$ by the Salinas River 921 and the 0.27 contribution to SMB.

$\begin{array}{llll}922 & \text { Period } & \begin{array}{l}\text { Total discharge } \\ \left(\times 10^{3} \mathrm{~m}^{3} / \text { year }\right)\end{array} & \begin{array}{l}\text { SMB contribution } \\ \left(\times 10^{3} \mathrm{~m}^{3} / \text { year }\right)\end{array} \\ 923 & 1910-1945 & 373^{1} & 101^{2} \\ 925 & 1940-1989 & 209 & 56 \\ 926 & 1989-2011 & 126 & 34\end{array}$

927 1. River discharge of beach sand based on measurements between 1929 and 1945.

928 2. Beach sand accretion measured using shoreline surveys.

929

930

931

932 Table 4. Sand Budget for SMB Southern Sub-cell. Values in $\mathrm{m}^{3} /$ year $\times \mathbf{1 0}^{3}$. 933 Uncertainties are presented with the values.

934 1940-1989 1989-2011

935

936

937

938

939

940

941

942

943

944

945

946

947

948

949

Dune Erosion

Dune Erosion $\mathrm{x}$ compatibility factor, 0.8

Beach Erosion

Littoral Transport out

Residuals

$\begin{array}{cc}11 & 6 \\ 9 \pm 2 & 5 \pm 1 \\ 12 \pm 2 & 5 \pm 1 \\ -20 \pm 4 & -10 \pm 4 \\ 0 \pm 8 & 0 \pm 6\end{array}$




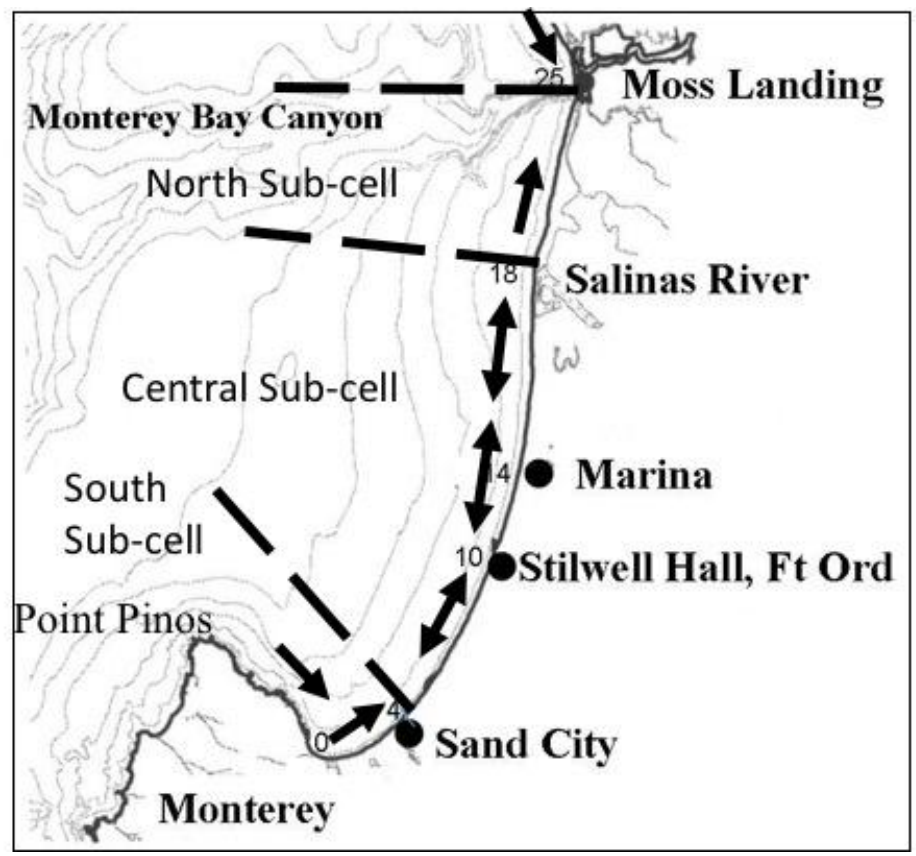

955

956 Figure 1. Map of Southern Monterey Bay. Dominant features are the Monterey Bay 957 Submarine Canyon, bulge of sand at the Salinas River, and Point Pinos headland at the 958 southern end. Littoral cells are delineated. The distances in km relative to Wharf II (0) in 959 Monterey are shown. The arrows indicate the direction of sediment transport. The dark 960 circles are the locations of video stations. 


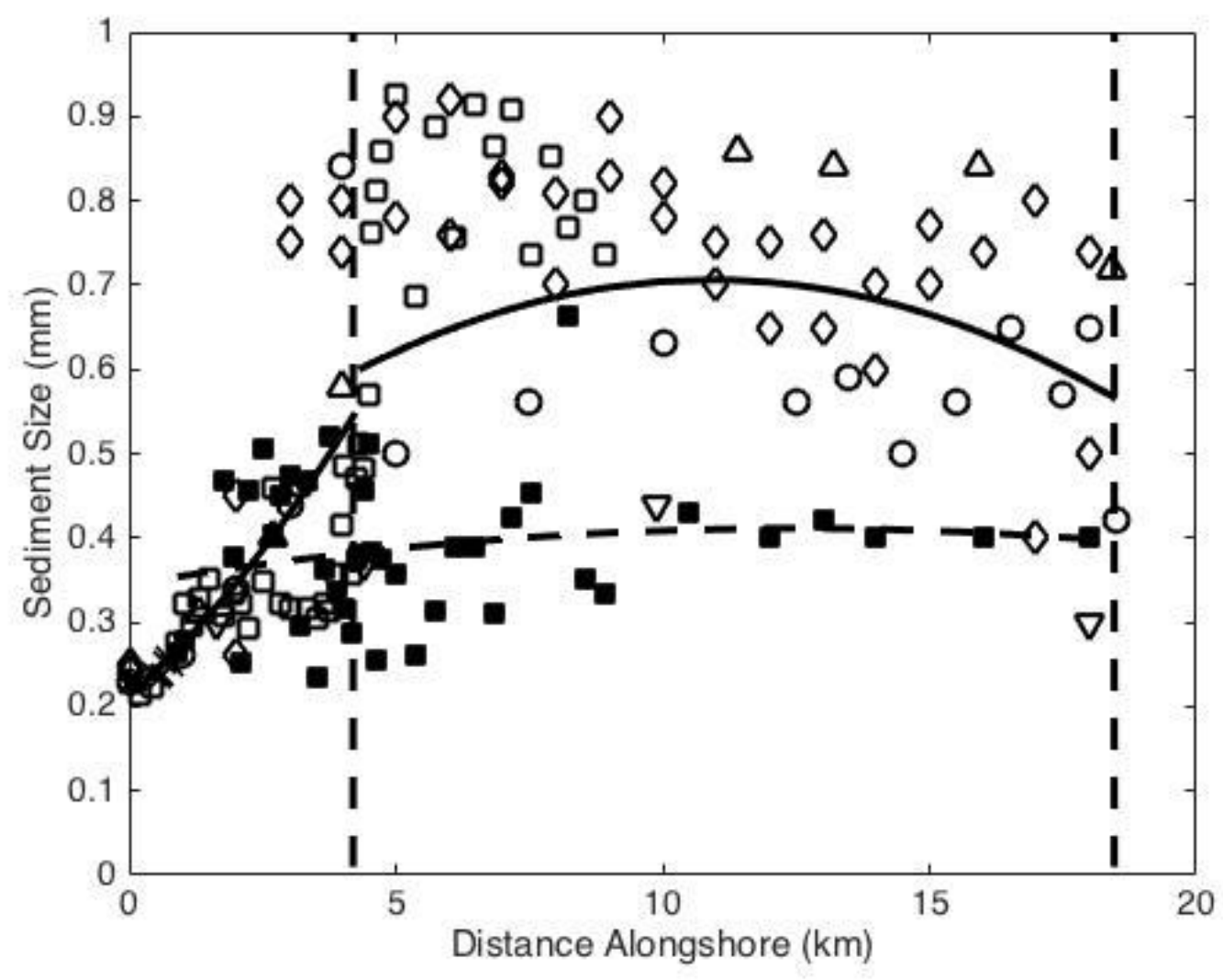

965

966 Figure 2. Alongshore distribution of mean sediment size $(\mathrm{mm})$ of beach and dune sands.

967 Beach sand (open symbols) collected at mean tide level by Sayles (1965) triangles;

968 Dorman (1968) squares; Combellick (1976) diamonds; Dingler and Reis (2001) inverted

969 triangles; and collected at $+1 \mathrm{~m}$ MSL by Clark and Osborne (1977) and Clark and

970 Osborne (1982) circles. Dune samples (closed symbols) collected by Dorman (1968),

971 Clark and Osborne (1977) and the author. Polynomial regression fits indicated by solid

972 line for beach sand and dashed line for dune sand. The central sub-cell is delineated as

973 between the vertical dashed lines.

974

975

976

977

978

979 


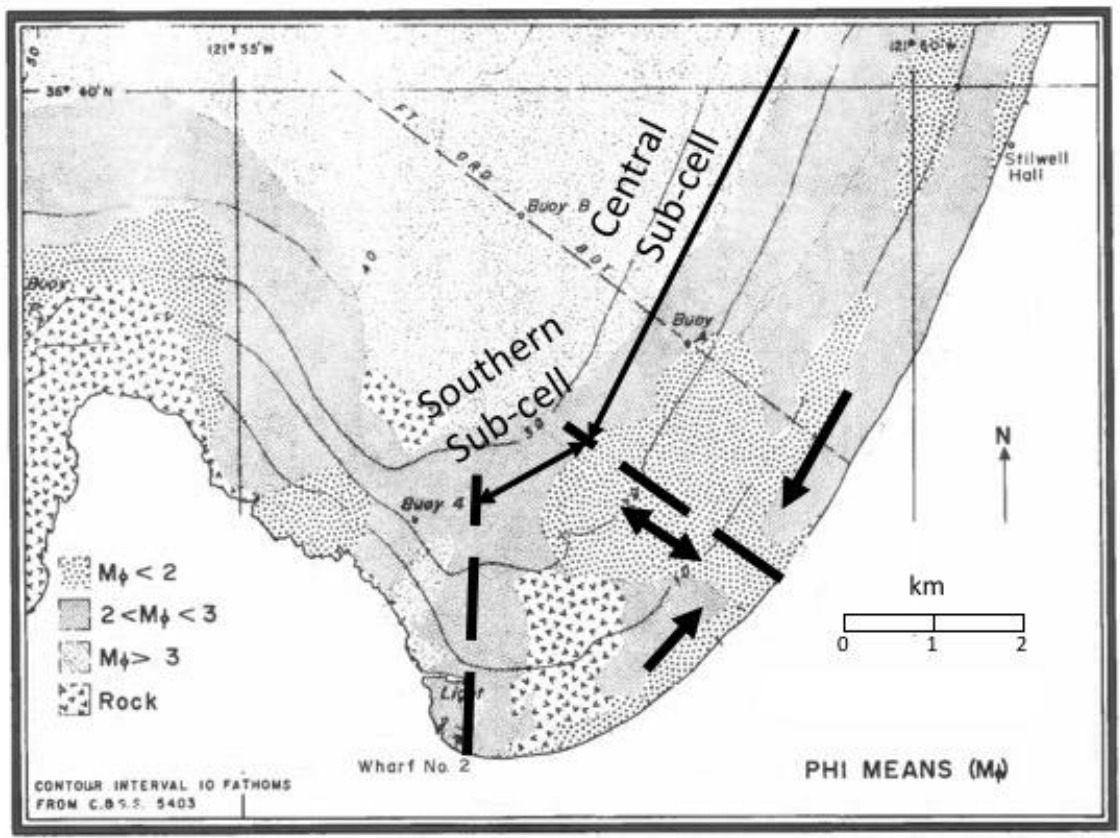

983 Figure 3. Mean-grain-size (phi units) in the southern bight of Monterey Bay showing 984 confluence of sediments at Sand City (modified from Dorman, 1968). Arrows indicate 985 direction of sediment transport. The littoral sub-cells are indicated.

986

987

988

989

990

991

992

993 


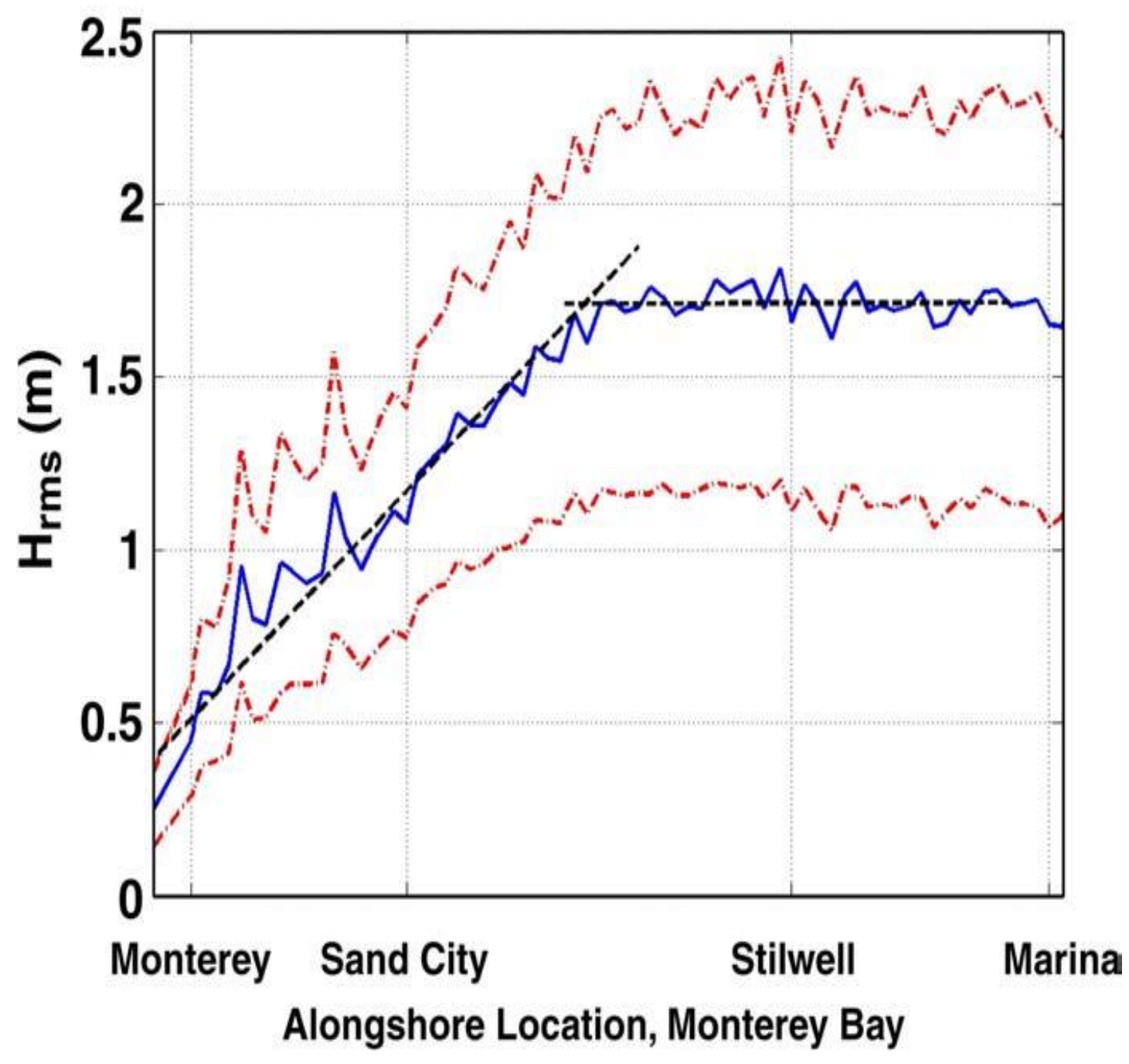

Figure 4. Model-predicted rms wave heights at breaking along the shoreline of southern Monterey Bay, averaged over October 2007 to April 2008. Data spread ( \pm one standard deviation) is shown by dash-dot lines. Dashed lines on top of main curve indicate mean alongshore slopes of wave heights on southern and northern sections of the shoreline between Monterey and Marina. (After Orzech et.al., 2010). 

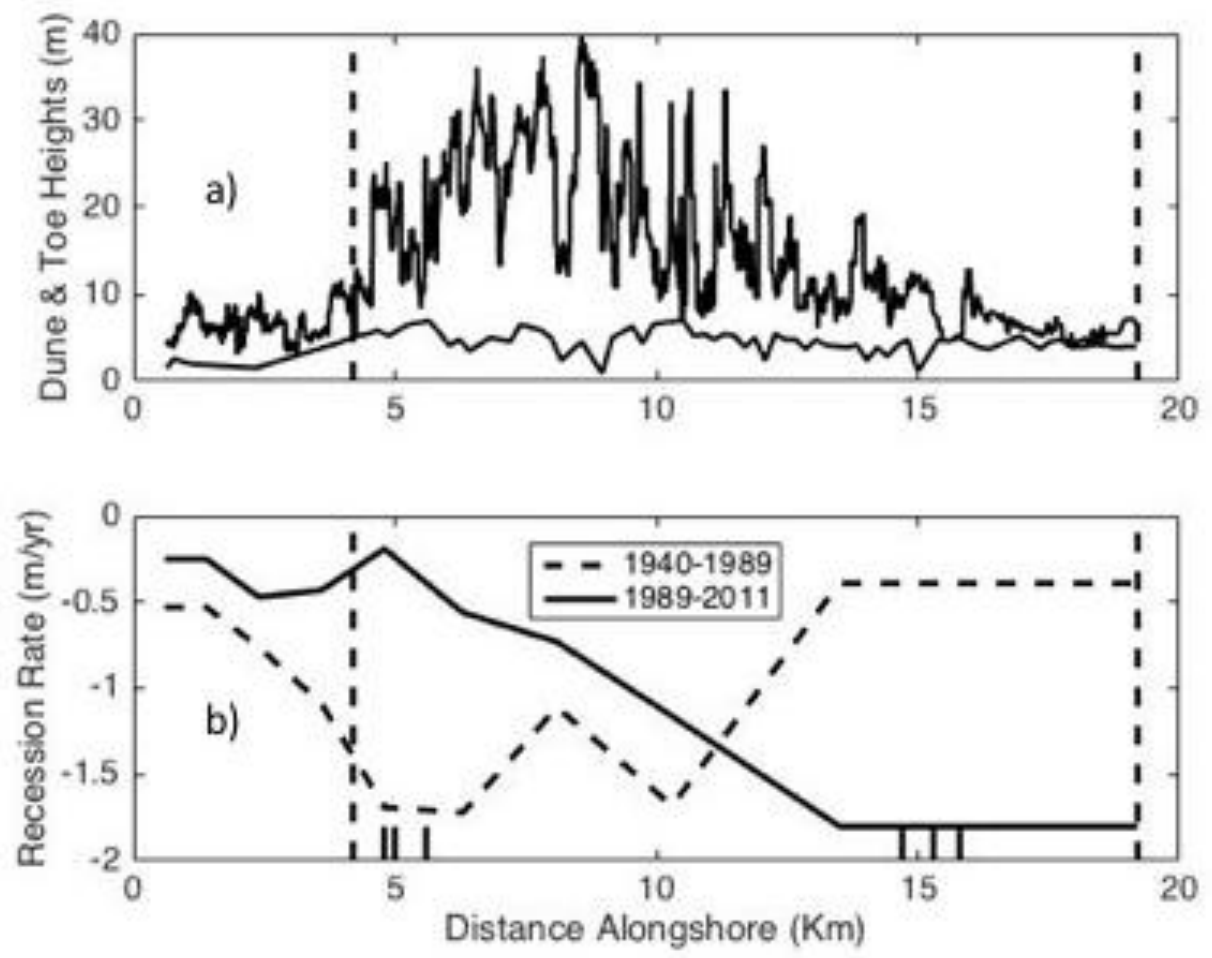

1004 Figure 5. a) Alongshore variation of dune height and due toe elevation relative to MSL. The central littoral sub-cell is delineated as between the vertical dashed lines; $b$ ) Alongshore variation of dune recession rates during time of intensive dragline mining (1940-1989) and after dragline mining ceased with only the dredge-pond sand mine in Marina operating (1989-2011). The location of the five drag-line sand mines plus the 1009 dredge-pond sand mine (most north) are indicated by the short vertical lines on the 1010 horizontal axis. 


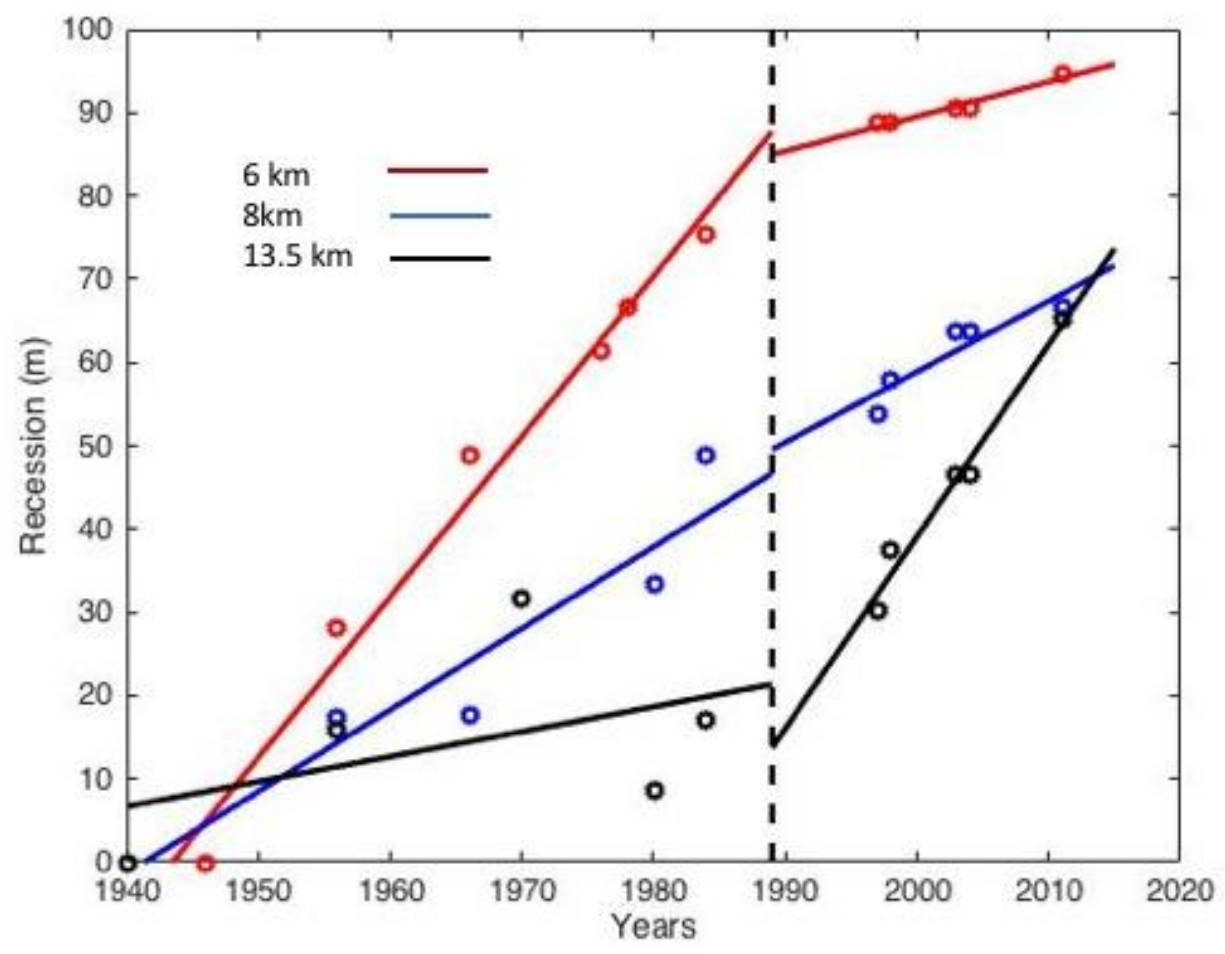

1021 Figure 6. Recession as a function of time at various alongshore locations relative to 1022 Wharf II with linear regression fit to periods 1940 to 1989 during the time of significant 1023 drag-line sand mining and 1989-2011 after the drag mines were closed. The vertical 1024 dashed line indicates 1989. 


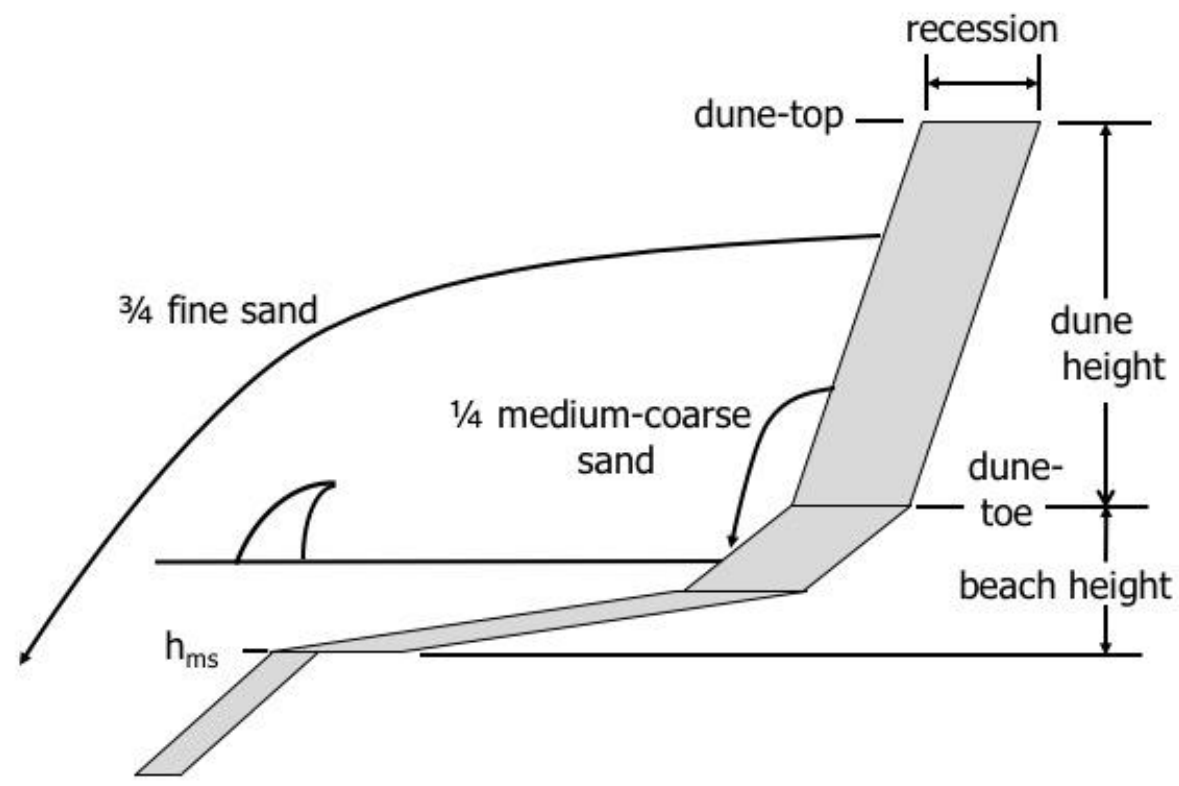

1038 Figure 7. Cross-section schematic of dune transitioning to a steep beach and then to a 1039 low-tide terrace bar all recessing at the same rate. One-fourth of the recessing dune 1040 volume is composed of medium to coarse sand which is transferred to the beach. The 1041 remaining fine sand is transferred offshore. The dune height is the difference in 1042 elevations between the dune-top edge and dune toe. The beach height is the difference in 1043 elevations between the dune toe and the offshore limit of medium sand (grain size $>0.25$ $1044 \mathrm{~mm}), \mathrm{h}_{\mathrm{ms}}$. 


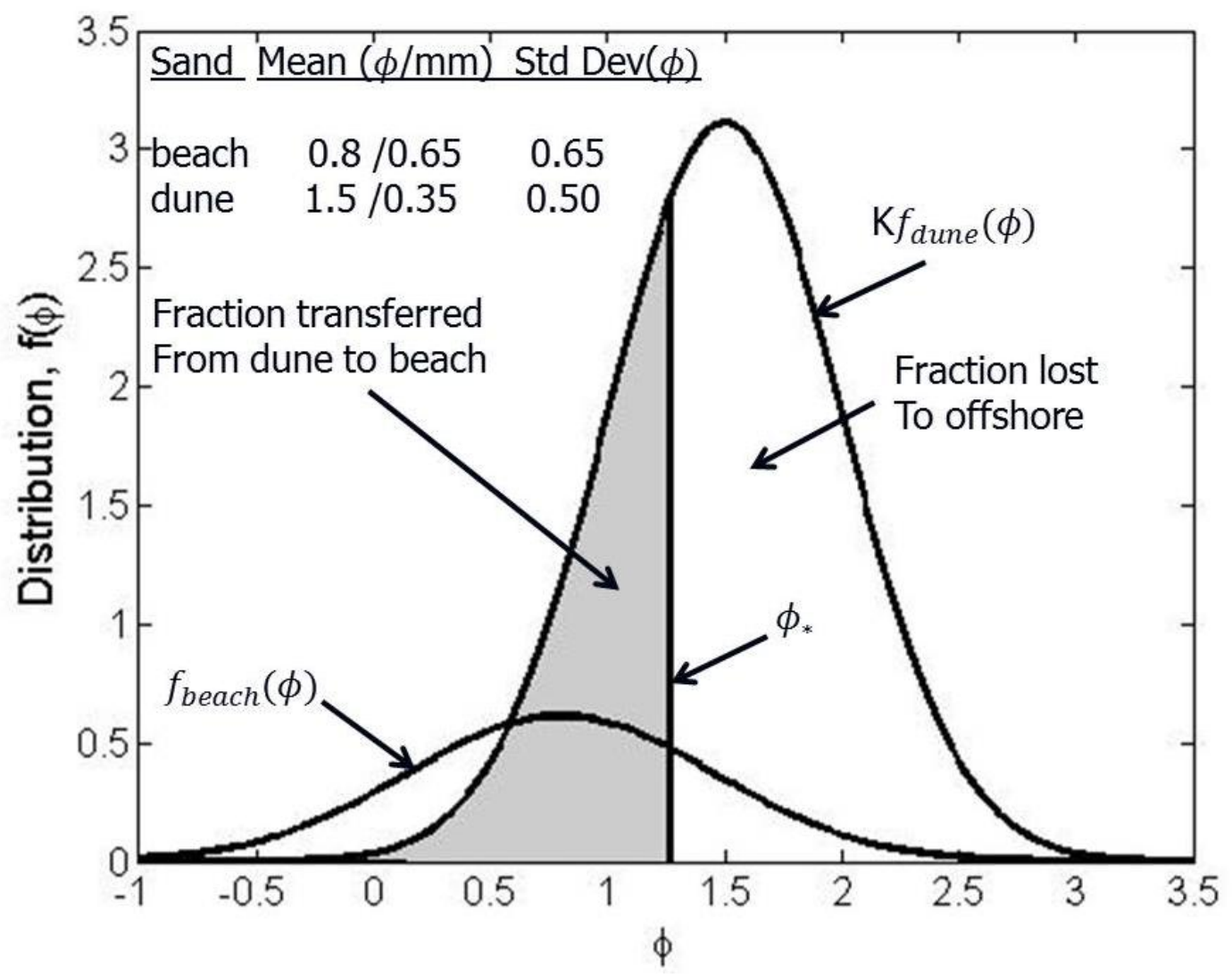

1054 Figure 8. Distributions of dune $f_{\text {dune }}(\phi)$ and beach $f_{\text {beach }}(\phi)$ sand size (phi units) demonstrating how the overfill ratio is calculated. The truncated distribution of the

1056 fraction of sand transferred from the dune to the beach (shaded area) must equal the area and have the same mean grain-size as $f_{\text {beach }}(\phi) . K$ is the number of units of dune sand required to match the beach sand. Compatibility factor is defined equal to $1 / \mathrm{K}$. Average alongshore mean grain-size and standard deviation values (phi units) for SMB are given. 


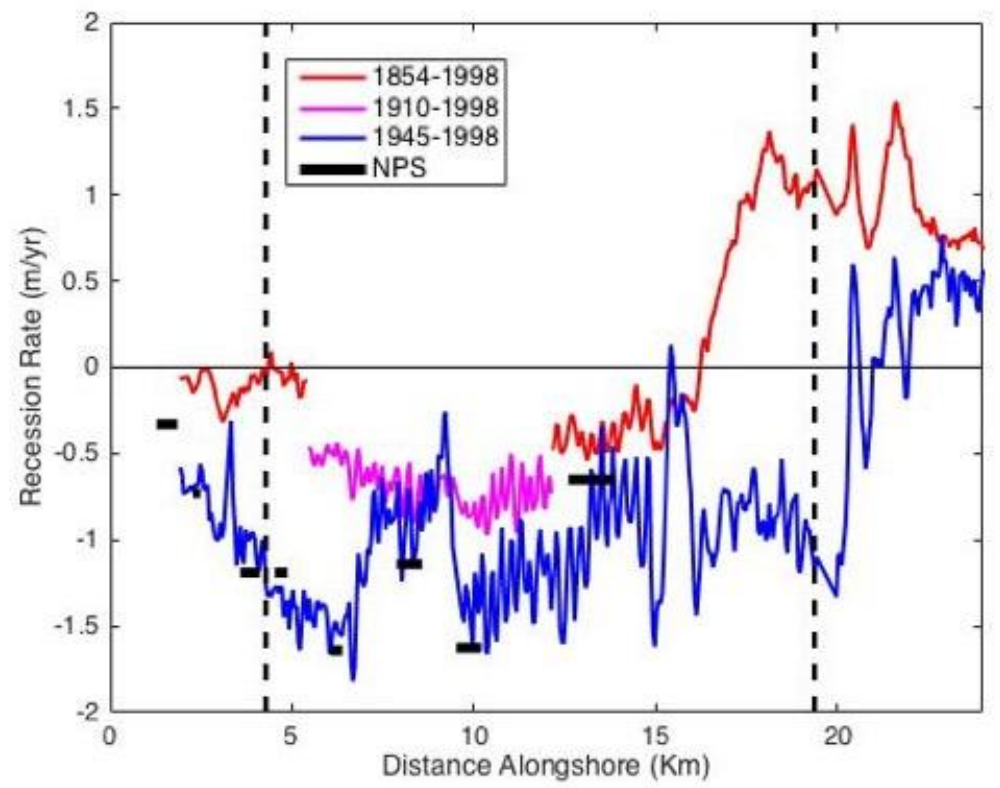

1068

1069

1070 Figure 9. Long-term shoreline recession rates composed of shorelines from 1854 to 1998 1071 (red), a section from 1910 to 1998 (magenta) and short-term from 1945 to1998) shoreline 1072 recession rates (m/year) calculated by the USGS (Hapke, et al., 2006). The dune-top 1073 recession rates by NPS are shown for comparison (broad solid lines). The central littoral 1074 sub-cell is delineated as between the vertical dashed lines. 


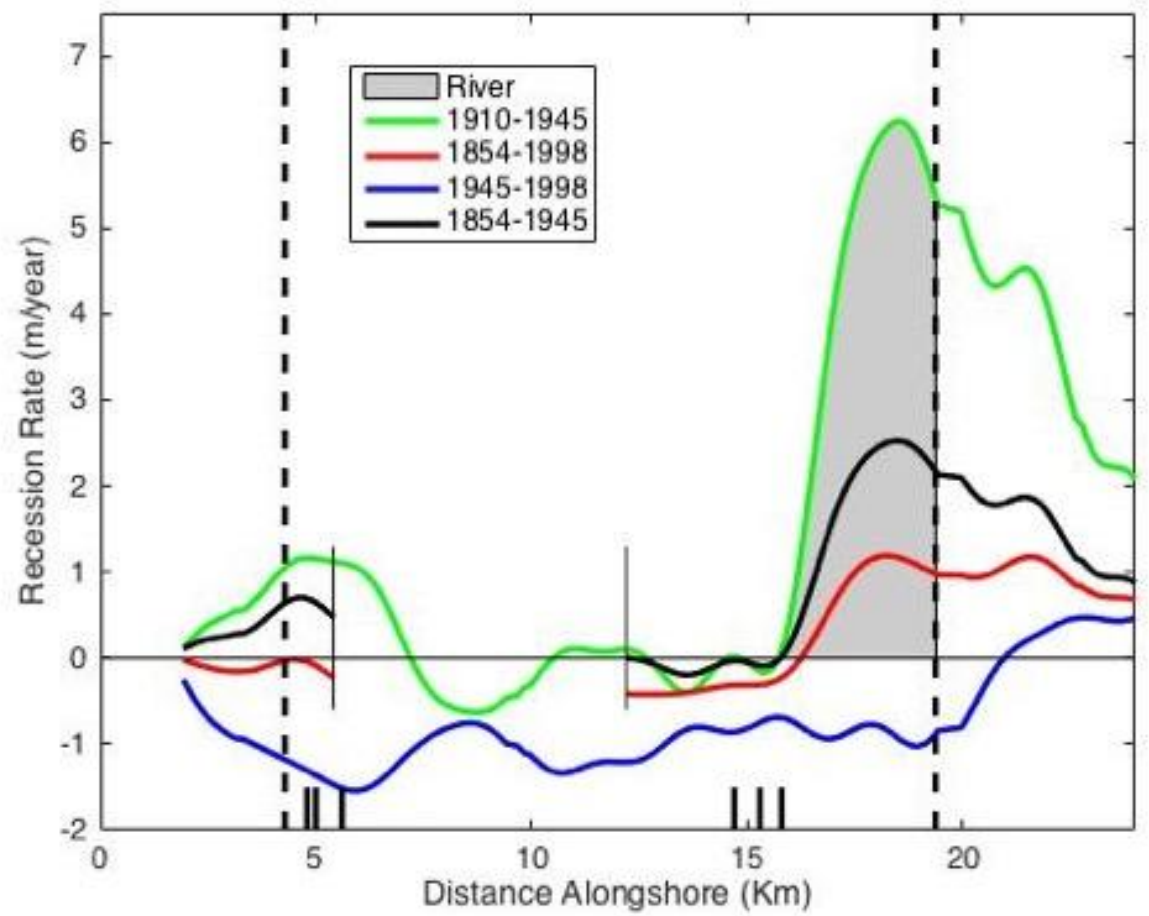

1087 Figure 10. Filtered long-term (1854-1998; red line) and short-term (1945-1998; blue line) 1088 shoreline recession rates (m/year) calculated by the USGS (Hapke, et al., 2006). Prorated 1089 shoreline recession rates are shown for 1854-1945 (black line), 1910-1945 (green line) 1090 and the southerly discharge of sand from the Salinas River (1910-1945; fill area). The central littoral sub-cell is delineated as between the vertical dashed lines. The thin vertical lines delineate the 1910 to 1998 section between 5.4 and $12.2 \mathrm{~km}$ alongshore. The

1093 location of the five drag-line sand mines plus the dredge-pond sand mine (most north) are indicated by the short vertical lines on the horizontal axis.

1095

1096

1097

1098

1099 


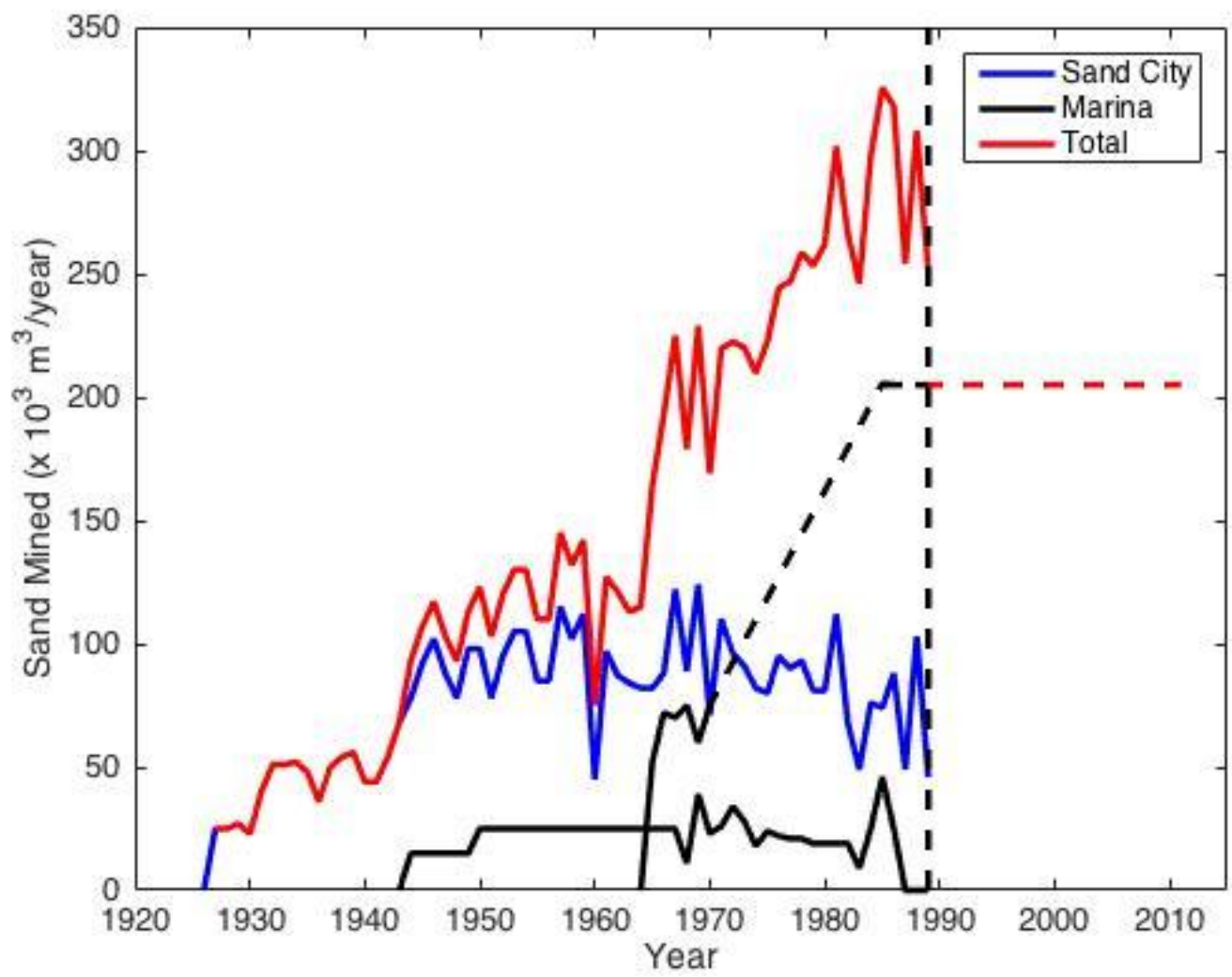

1100

1101

1102 Figure 11. Annual amounts of sand mining reported to State Lands Commission (solid 1103 lines) and estimated dredge pond annual amounts (dashed lines) at Sand City (blue line) 1104 at Marina (black line) and total (red line). Vertical dashed line indicates when the drag1105 line mines were all closed in 1989. Sand mined after 1985 is estimated based on reported 1106 amount in 2000. 

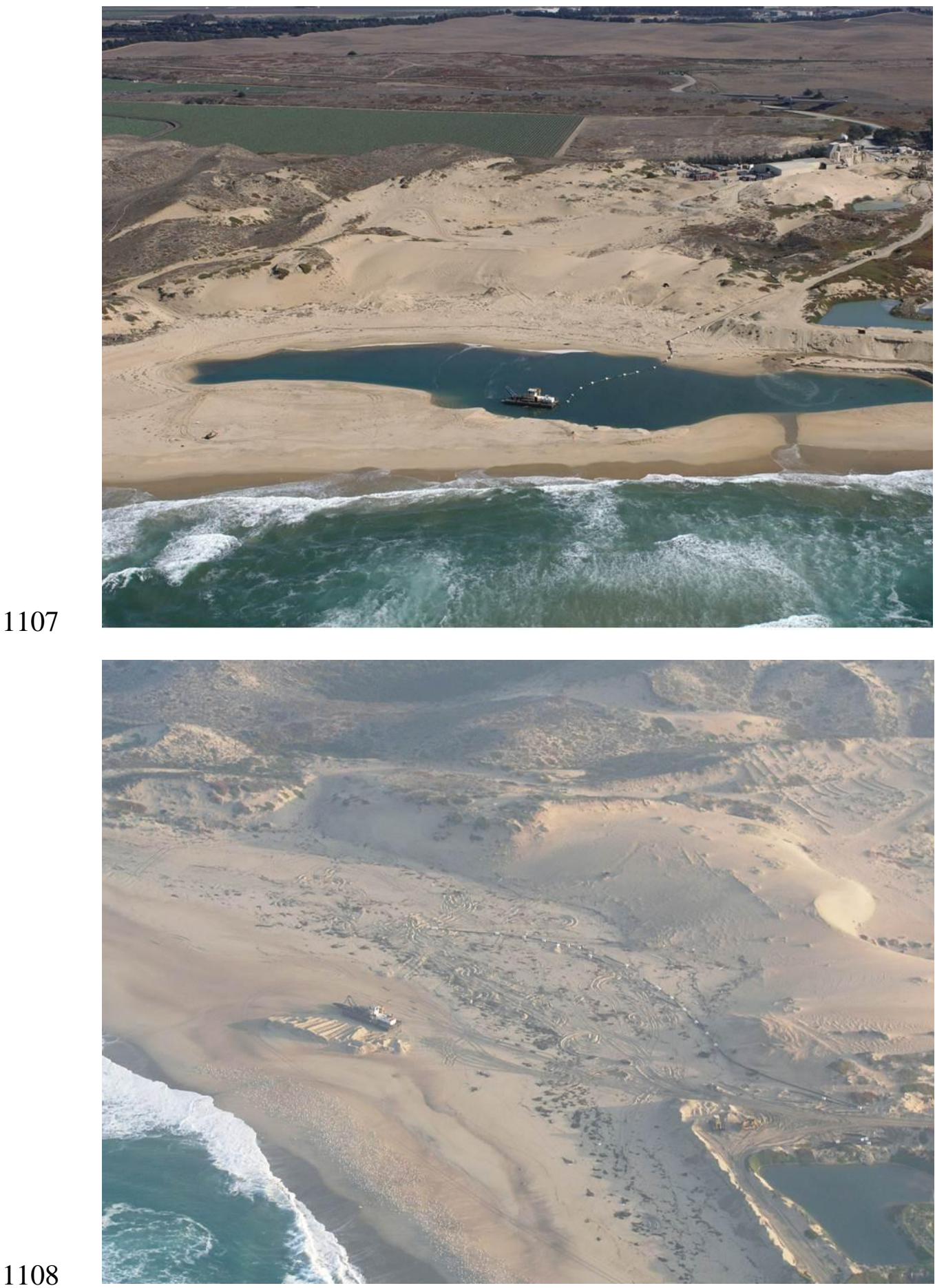

1110 Figure 12. Aerial photographs of dredge pond during operation in April 2005. Copyright 11112005 Kenneth and Gabrielle Adelman, California Coastal Records Project, www.

1112 Californiacoastline.org (upper panel) and when dredge pond is filled with sediments in 1113 the winter (photo taken by Rob Wyland 15 January 2008) (lower panel). 